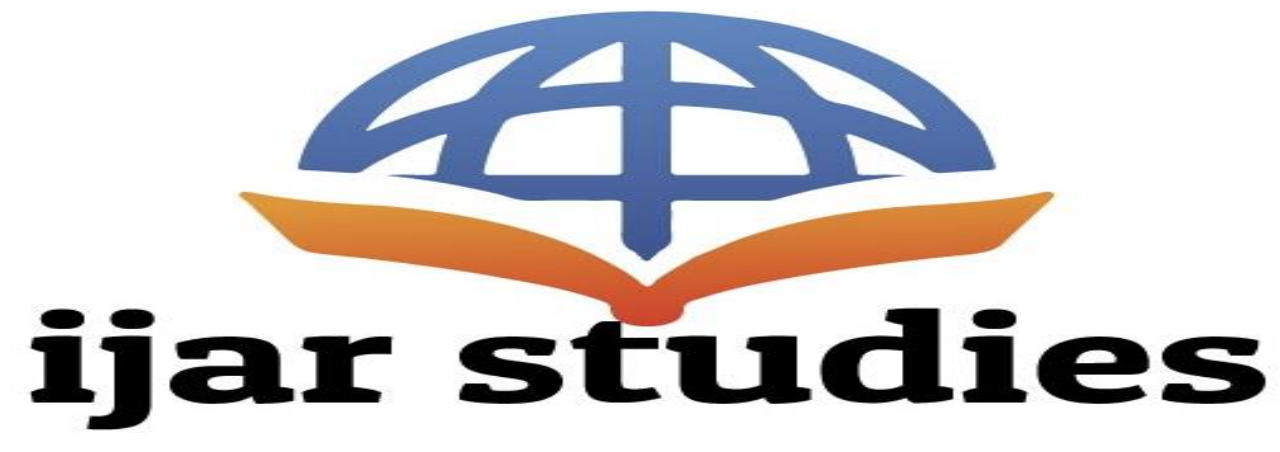

International Journal of Academic Researchs Studies Year:2, Number:3, December 2019, ss. 15-32

Article Arrival Date/ Yayın Geliș Tarihi 12.11.2019
The Publication Date/Yayınlanma Tarihi 29.12.2019

ISSN: $2667-4823$

Aralık / December 2019, 3

Makale Bilgisi / Article Information

http://dx.doi.org/10.29228/ijarstudies.40103

شعرية الإيقاع الداخلي لقصيدة النثر السعودية

قراعات لنماذج مختارة

د. حمدان محسن عو اض الحارثي

جامعة الباحة

المملكة العربية السعودية 


\section{شعرية الإيقاع الداخلي لقصيدة النثر السعودية}

لم يعد الفعل الإبداعي الحديث في ظل حضور مكتّف للوعي الجماليّ التجريبيّ عملاً مجازيّاً بل يُصسار إلى فعل تركيبي

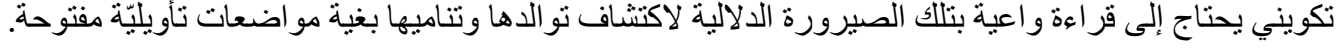

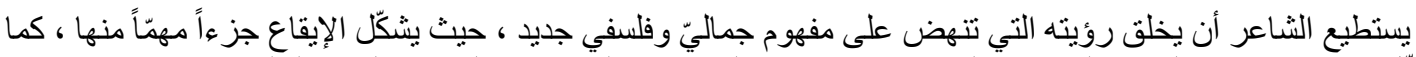

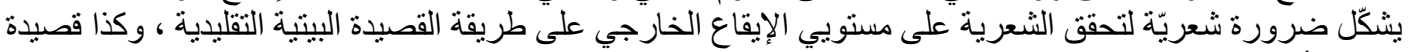

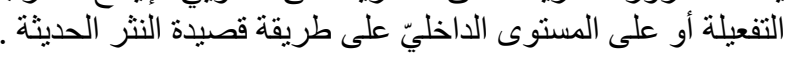

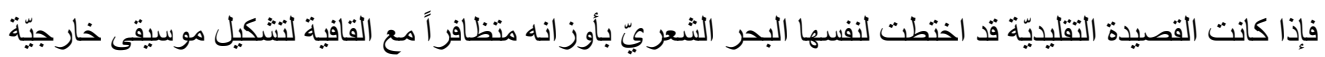

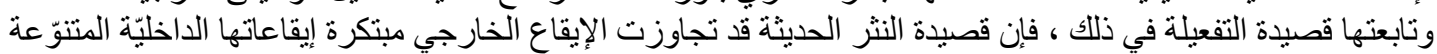

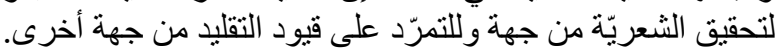

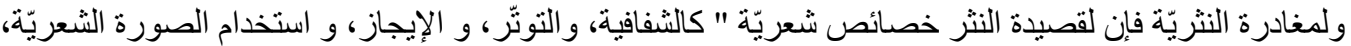

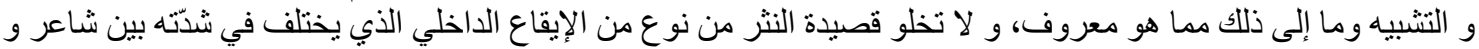

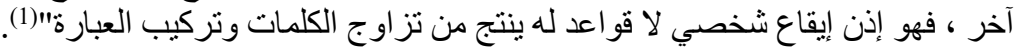
وتتظر قصيدة النثر إلى الشعر كتجربة حرة غير قابلة للتأطير ورسم الحدود باعتبار ها نظرة شخصيّة للحياة وللأثياء.

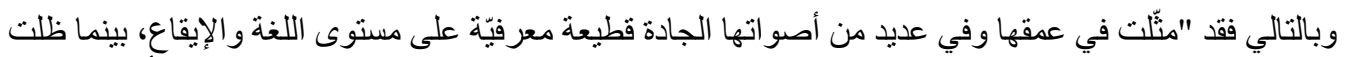

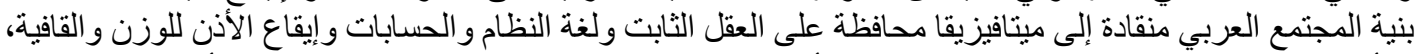

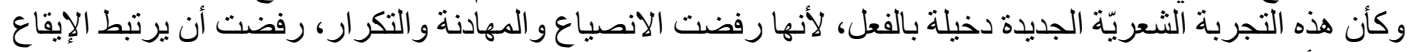

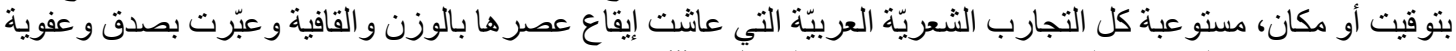

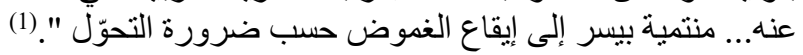

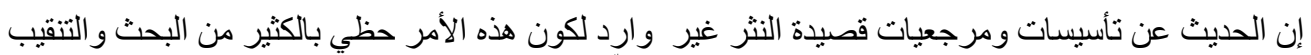

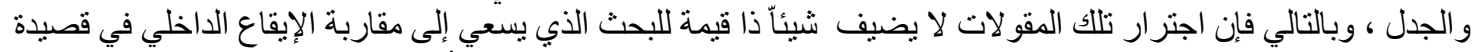

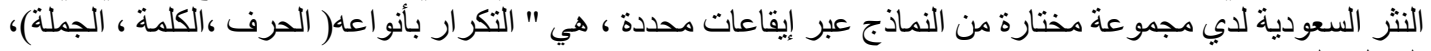
التقابل /التضاد.

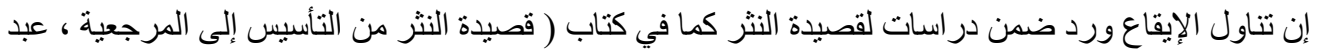

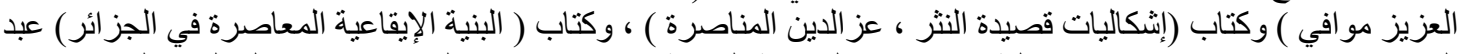

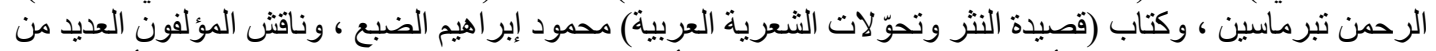

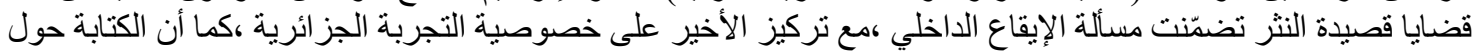

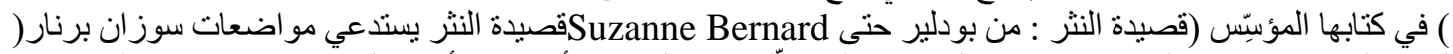

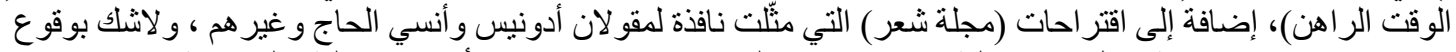

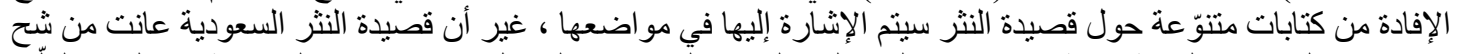

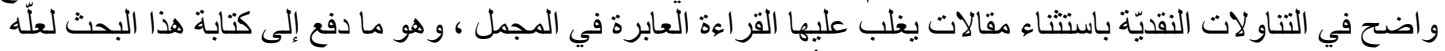

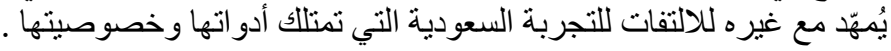

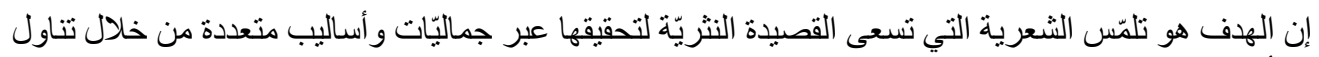

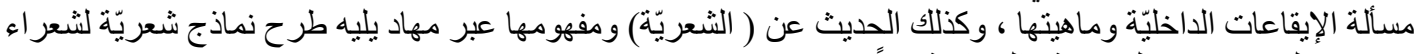

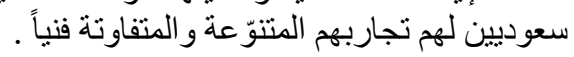

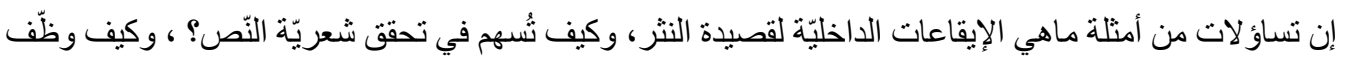

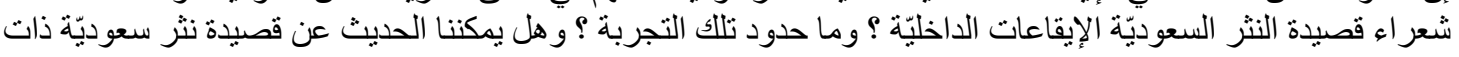

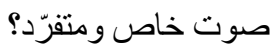

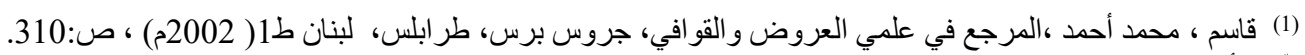

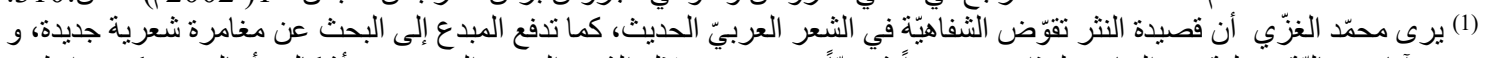

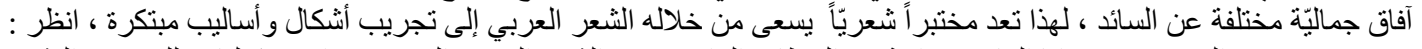

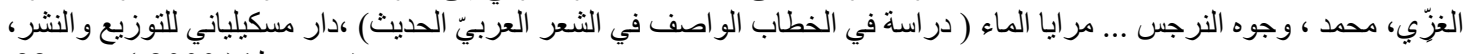

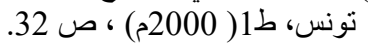




\section{شعرية الإيقاع الاخلي لقصيدة النثر السعودية}

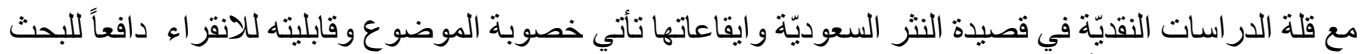

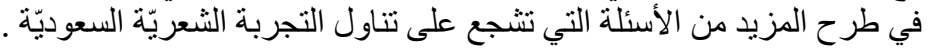

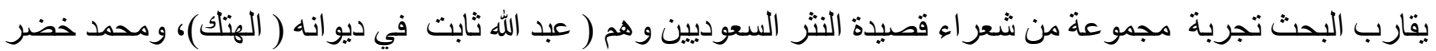

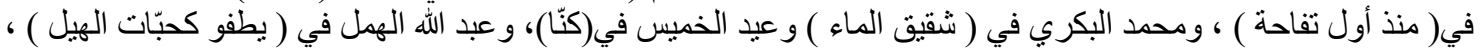

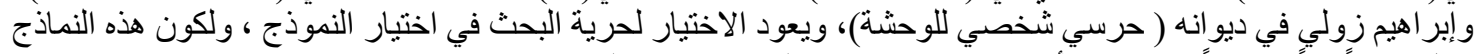

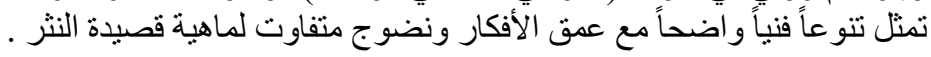

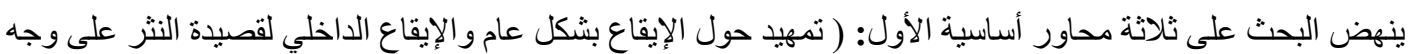

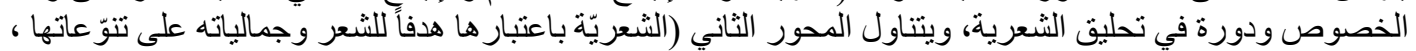

و الإيقاع واحد منها).

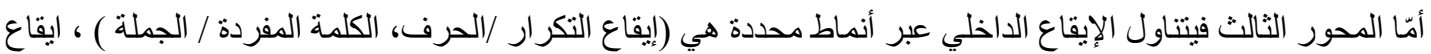

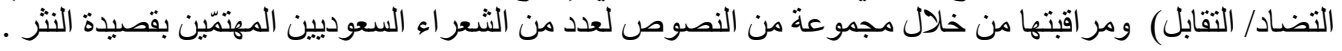

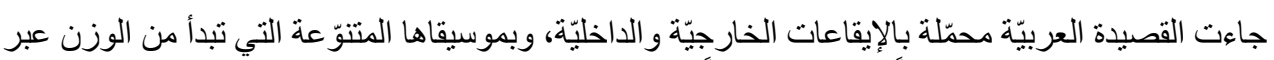

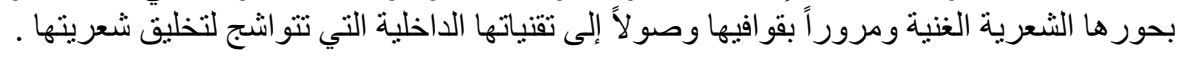

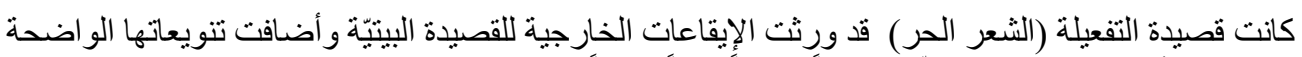

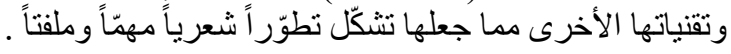

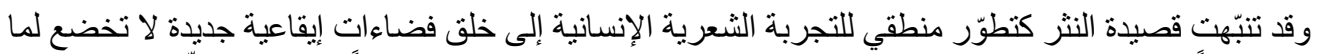

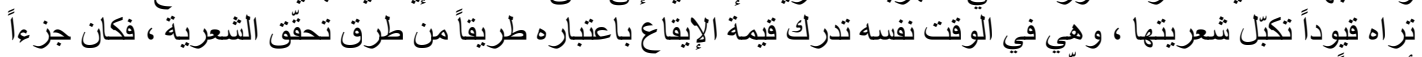

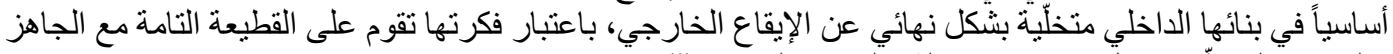

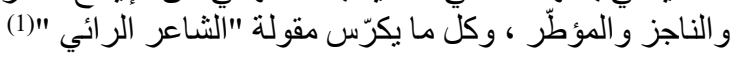

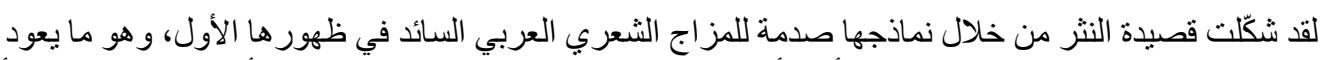

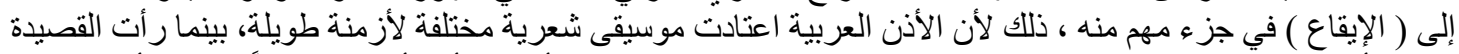

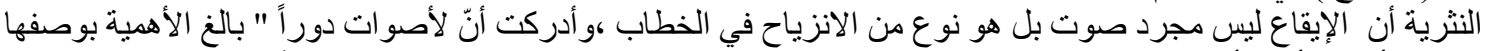

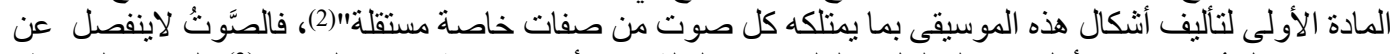

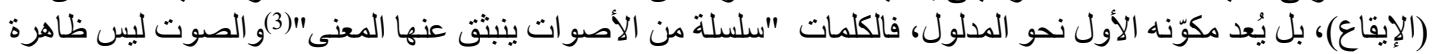

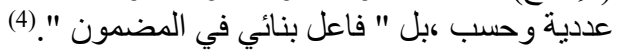

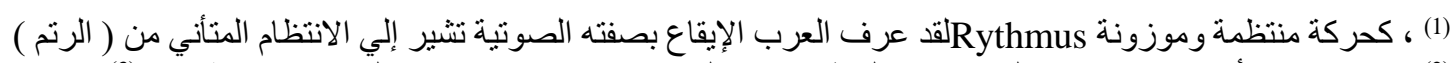

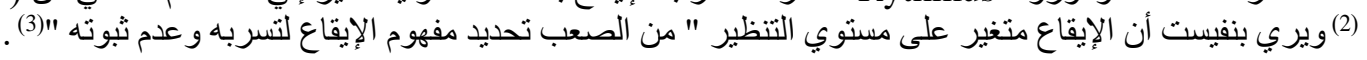

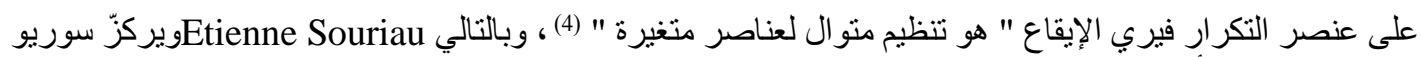

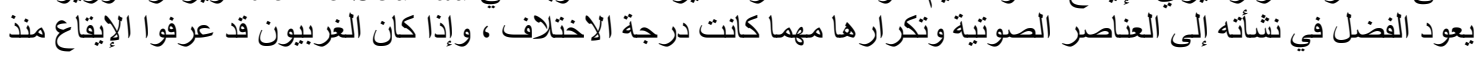

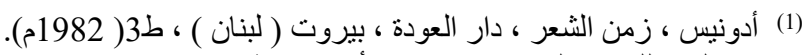

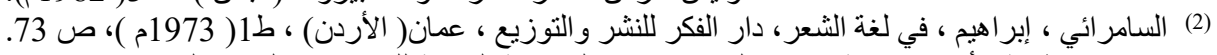

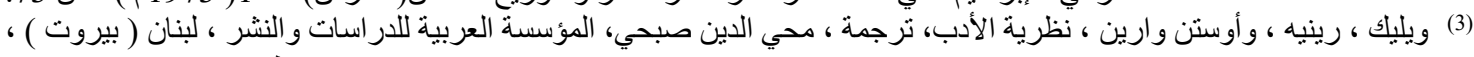

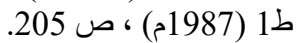

(4) عبيد، محمد صابر ، القصيدة العربية الحديثة بين البنية الدلالية والبنية الإيقاعية، منشور ات اتحاد الكتاب العرب، دمشق ، ط1(2001م)

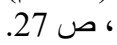

$$
\text { (1) عبد الحميد ، محمد ، في إبقاع شعرنا العربيّ ، دار الوفاء للنشر ،ط1(2005م) ، ص } 2 .
$$$$
\text { (2) تبرماسين ، عبد الرحمن ، العروض وإيقاع الثعر العربي ، دار الفجر للنشر ، القاهرة ط1(2003م) ، ص } 80 .
$$

81 (3) السابق ،ص 81 (3)

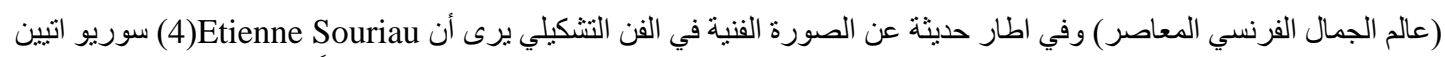

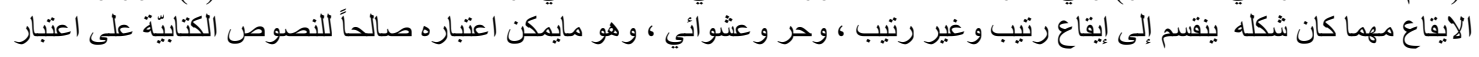




\section{شعرية الإيقاع الداخلي لقصيدة النثر السعودية}

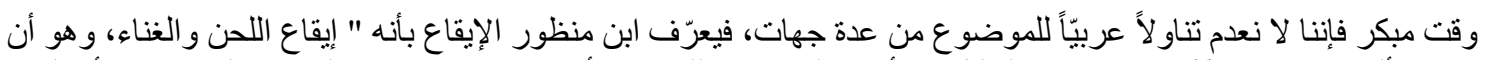

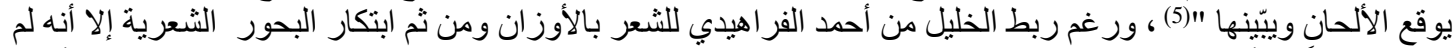

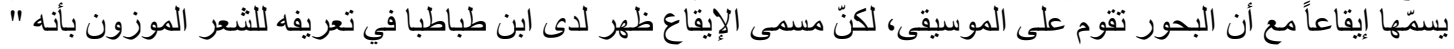

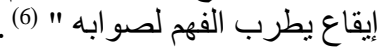

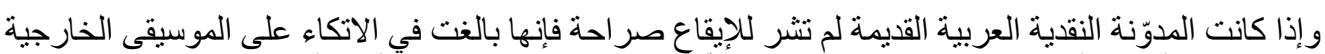

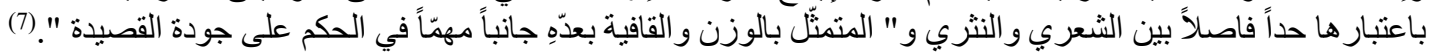

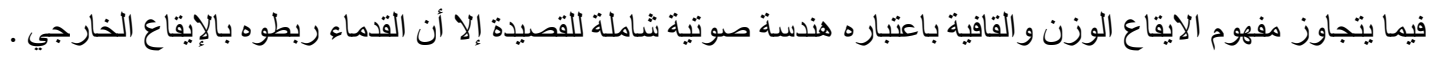

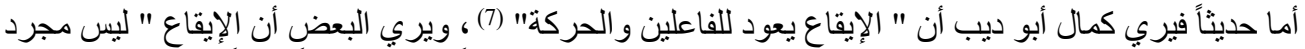

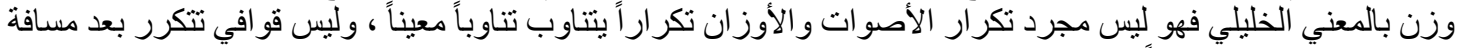

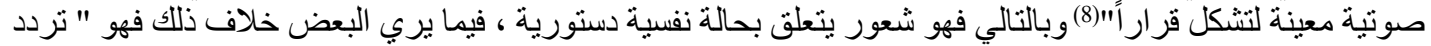

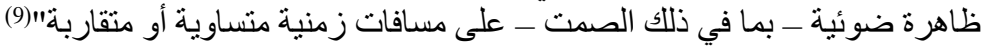

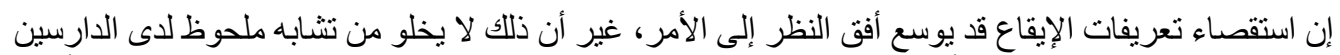

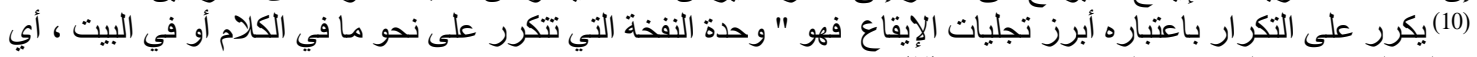
تو الي الحركات و السكنات على نحو منتظم " (11).

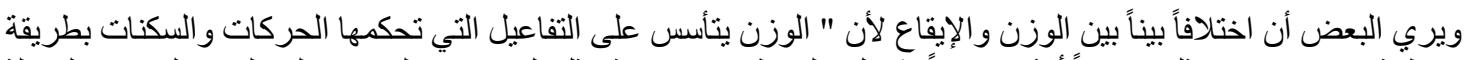
منتظمة بينما الإيقاع يمثل مفهوماً أكثر اتساعاً يشتنمل على ظو الهر بلاغية مثل الترصيع و التجنيس الداخلي، و التقسيم و المقابلة و المطابقة" (12).

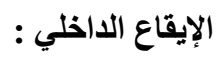
إذا كان الإيقاع الخارجي يتجلّى في الوزن و القافية " فإن الإيقاع الداخلي لا يتمثل في الهيكل الماتل، و إنما يتجنّّ

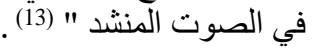

الحديث عن الايقاع بشكل عام من جهة ومن باب تداخل الأجناس الأدبية من جهة أخرى ـ انظر : سوريو ، اتيين، الزمان في الفنون

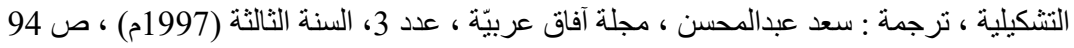

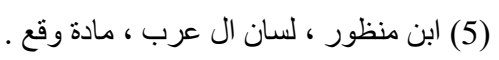

(6) بو منجل ، عبد الملك ، جدل الثابت والمتغير في النقا العربي الحديث ، عالم الكتب، ج2، ط1(2010م ) ، ص17.

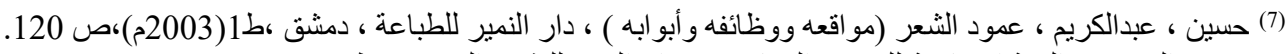

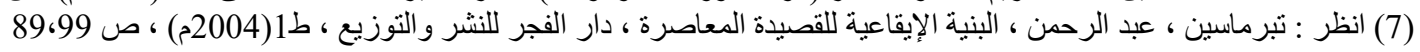

(8) سعيد ، خالدة ، حركية الإبداع ( دراسات في الأدب العربي الحديث)، دار الفكر ، بيروت (لبنان)، ط3 (1986م)، ص182.

(9) أحمد ، محمد فتوح ، الحداثة الثعرية (الأصول و التجليات ) ، دار غريب للنشر ، القاهرة ، ط1(2007م) ، 342 ـ 3 ،

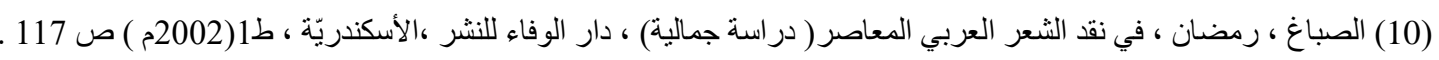

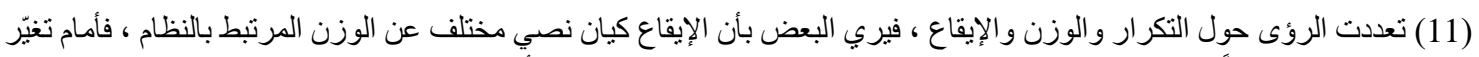

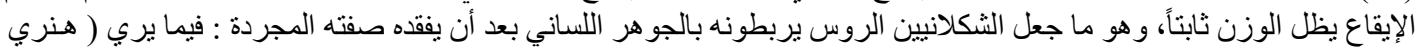

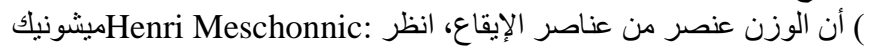

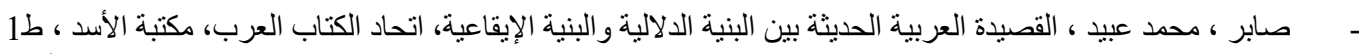

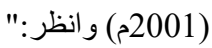

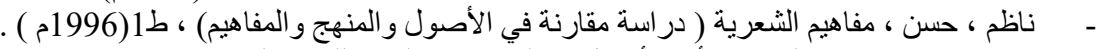

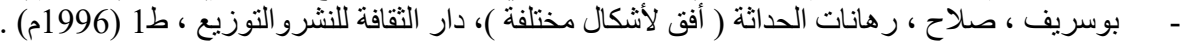

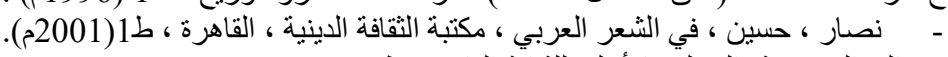

(12) مو افي ، عبد العزيز ، قصيدة النثر من التأسيس إلى المرجعية، المجلس الأعلي للثنافة القاهرة، ط1(2004م) ، ص118.

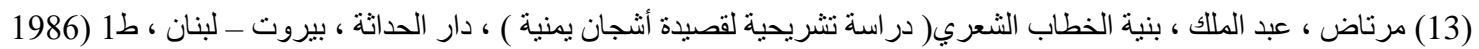

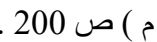




\section{شعرية الإيقاع الاخلي لقصيدة النثر السعودية}

وبالتالي فإن أبرز تمظهر اته" في القو افي الداخلية ، وضروب البديع ، وحروف الدد ، أو الهمس ، ومدى الانسجام

بين هذه الظو اهر وبين جو القصيدة " (i1)

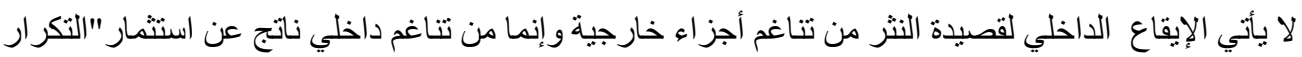

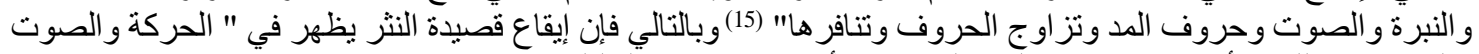

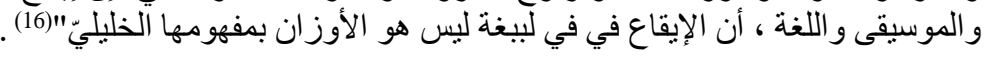

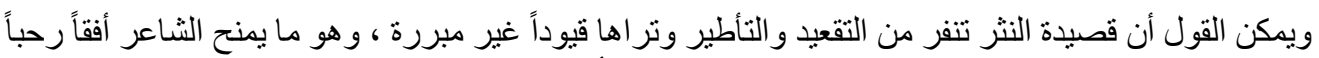

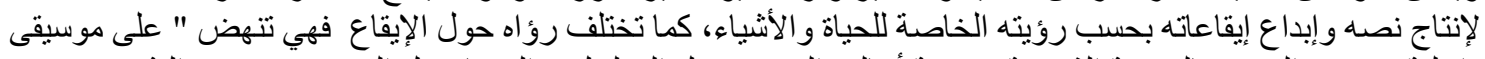

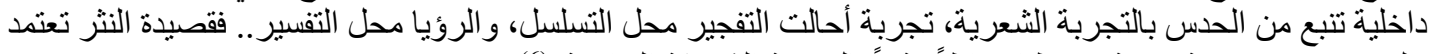

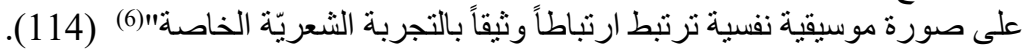

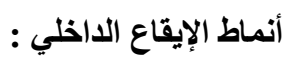

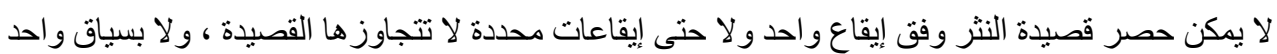

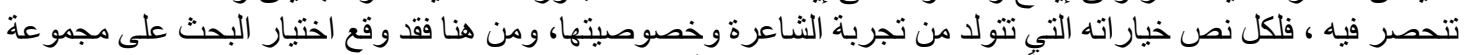

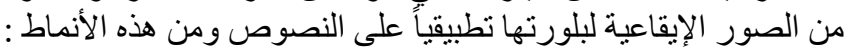

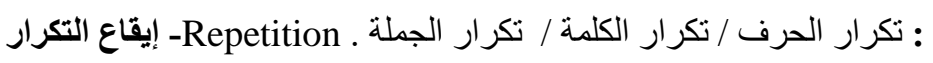
- إيقاع التقابل ( التضاد).

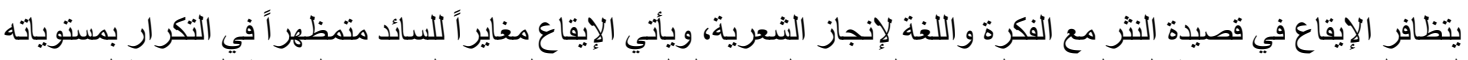

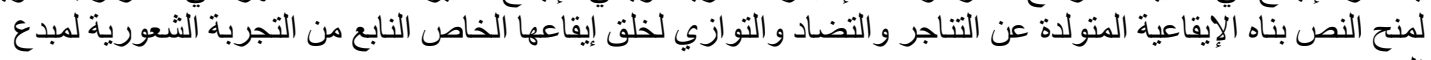
النص.

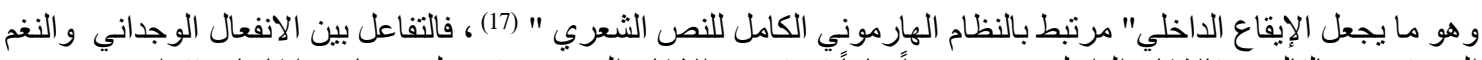

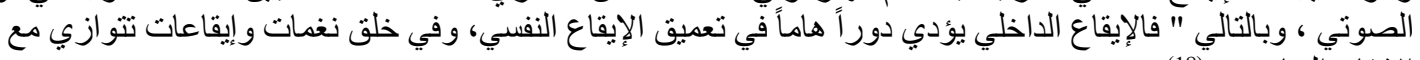

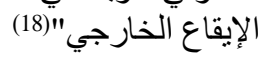

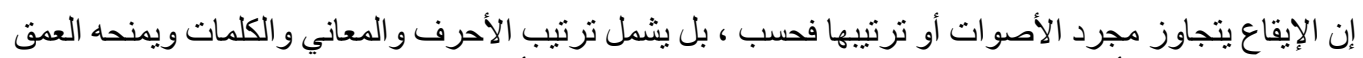

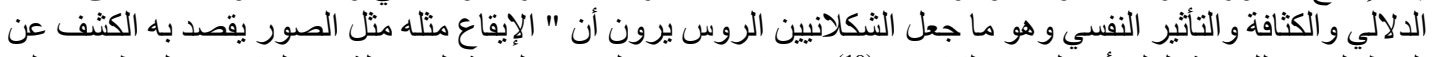

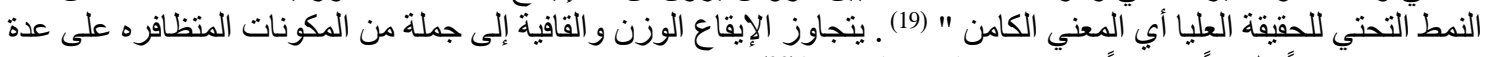

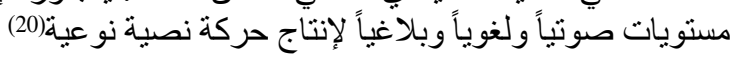

) الثعرية Poetics- : (

$$
\begin{aligned}
& \text { (14) سليمان ، خالد ، الجذور والأنساغ ( دراسة نقية في جديد القصيدة العربية المعاصرة ) ، ط 1(2009م) ، ص } 38 .
\end{aligned}
$$

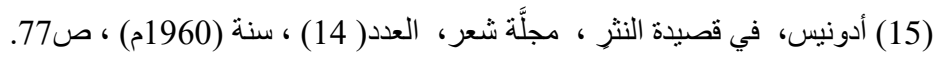

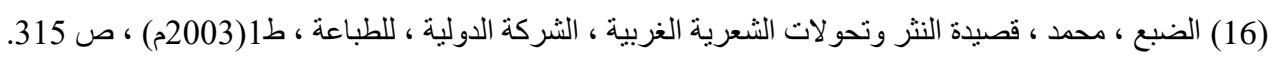

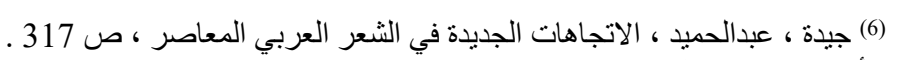

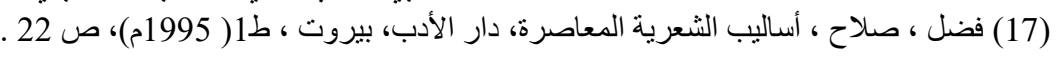

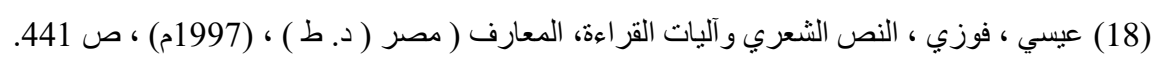

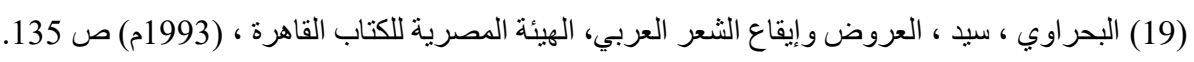

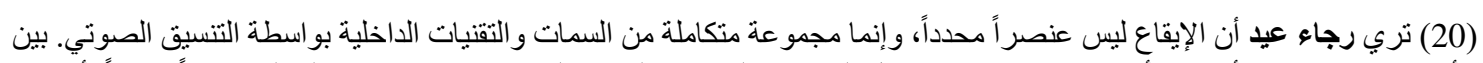

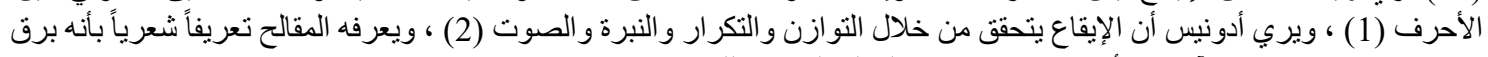

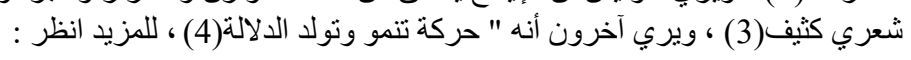

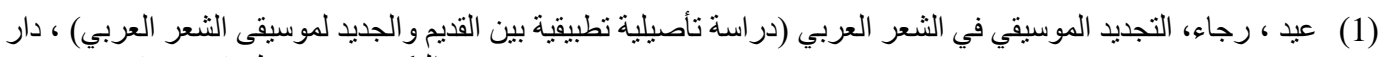

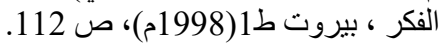

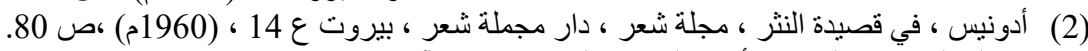

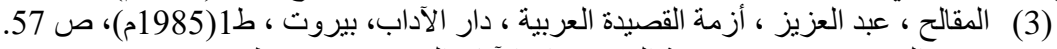

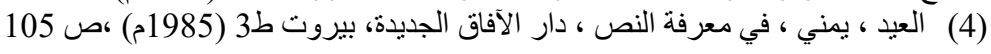




\section{شعرية الإيقاع الداخلي لقصيدة النثر السعودية}

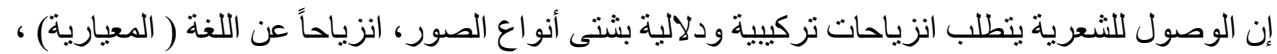

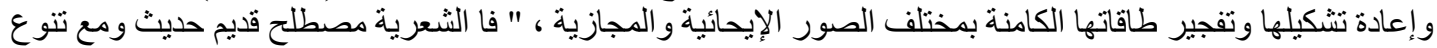
الدفهوم فإن فكرته هي البحث عن القو انين العلمية التي تحكم الإبداع " (21).

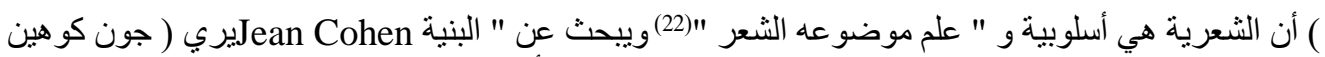

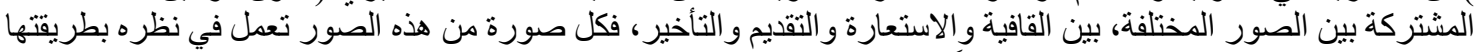

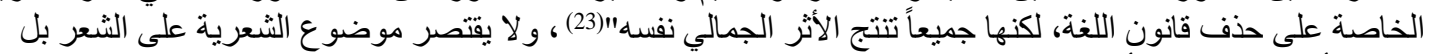

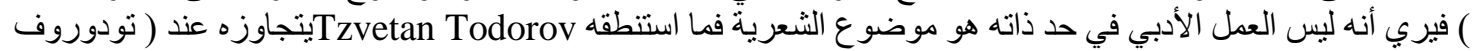
هو خصائص الخطاب النوعي الذّي هو الخطاب الأدبي "(24).

) رأيه فيرى أن الثعرية هي " الدراسة Roman Jacobsonومن منطلق الدر اسات اللسانية ييني جاكبسون ( اللسانية للوظيفة الثعرية في سياق الرسائل اللفظية "(25).

فتصبح الثعرية عنده لغوية قائمة على النفعية ووظيفتها التو اصلية المكونة من " المرسل / المرسل إليه / الرسالة / السياق /

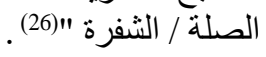

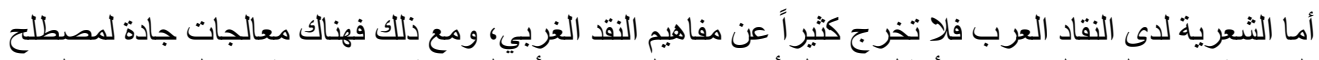

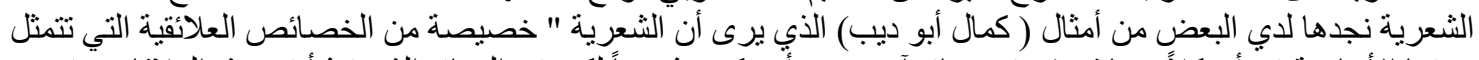

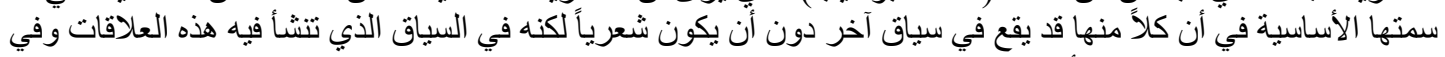

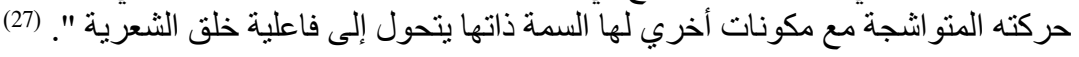

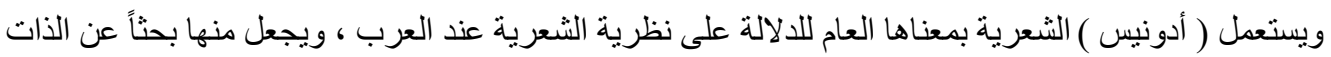

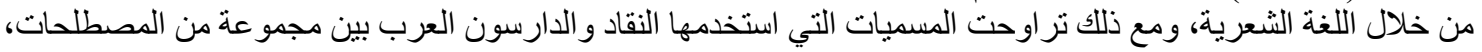

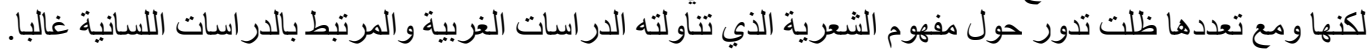

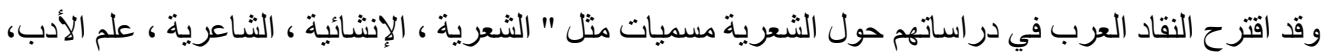
الفن الإبداعي ، فن النظم ، فن الشعر ، نظرية الثعر ، بويطيقا، بونتيك ) (28)

(21) ناظم ، حسن ، مفاهيم الثعرية ، دراسة مقارنة في الأصول والمنهج ، المركز الثقافي العربي، بيروت ، ط1 (1994م) ، ص 10. (22) كو هين ، جون ، بنية اللغة الثعرية، ترجمة ، محمد الو الي ومحمد العمري، دار توبقال المغرب، الدار البيضاء، ط1(1986م) ،ص

48 المرجع السابق ،ص 43

(24) تودوروف ، تزفيتان ، الثعرية ، ترجمة : شكري المبخوت و رجاء بن سلامة، دار توبقال ، المغرب، الدار البيضاء ، ط2 (23 )

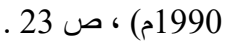

(25) المناصرة ، عز الدين ، علم الثعريات ( قراءة مونتاجية في أدبية الأدب ) ، دار مجدلاوي ، عمان ، (2007م) ، ص 284. (26) ناظم ، حسن ، مفاهيم الثعرية، دارسة مقارنة في الأصول والمنهج، المركز الثقافي العربي، بيروت ، ط1(1994م) ، ص 10.

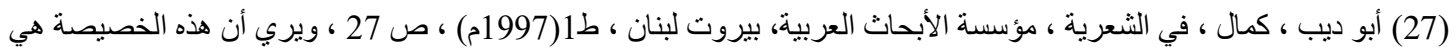

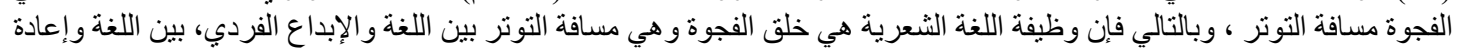
وضعها في سياق جديد بالكامل. (28) تبني النقّاد مجمو عة من المصطلحات للتعبير عن الثعرية ويمكن إيجاز ها في : ( الشعرية) قال بها : محمد الولي ، المسري ، شكري المبخوت، رجاء سلامة كاظم جهاد ، أحمد يطلوب ، الغذامي ( الإنشائية ) قال بها :

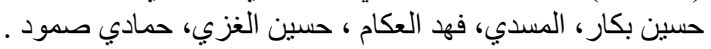

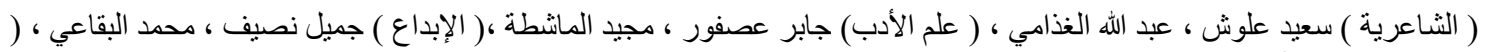

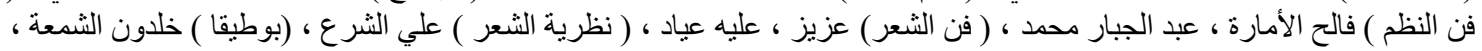

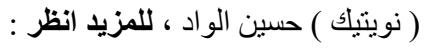

$$
\text { - ناظم، حسن ، مفاهيم شعرية : دراسة مقارنة في الأصول و المنهج ( مرجع سابق ). }
$$




\section{شعرية الإيقاع الاخلي لقصيدة النثر السعودية}

ومفاد القول أن " مفاهيم الثعرية مختلفة ومتتو عة، غير أنها اعتمدت على المجاز ات اللغوية بصورة عامة للكثنف

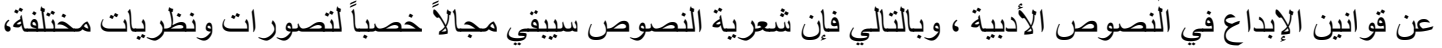
وييقي البحث عن الثعرية محاولة للعثور على بنية مفهومية هاربة" (29) .

المبحث الثالث (أنماط الإيقاع الداخلي) :

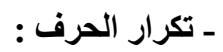

لا تسنطيع اللغة التعبير بثكل دقيق دون إيقاع صوتي لأن " الإيقاع هو المعني لأن اللغة لا تتتج المعني خارج نركيب إيقاعها الدلالي " (30).

و لا ينكر أحد ارتباط الصوت بالمعني ومنح الدلالة وجودها لأن " العلاقة بين الصوت و المعني ، إذ لا يمكن أن

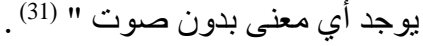

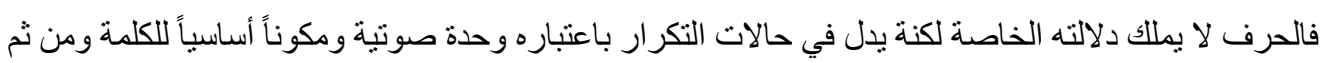

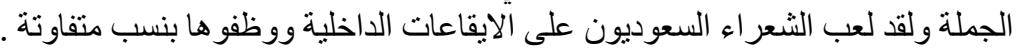

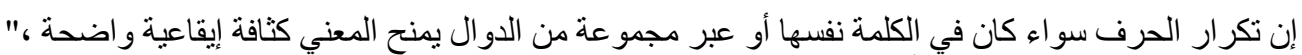

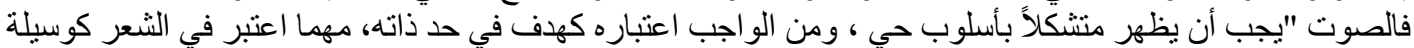

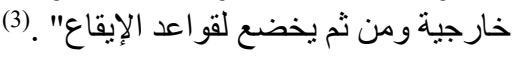
وتحت عن عنوان ( سقف )بتردد حرف ( السين) منذ العنوان مخلّفاً إيقاعاً جدير اً بالتأمل: سماء بالية تحمل أو هامها في سلة الأفكار تسقط قطعاً صغيرة. هذه السماء التي صـارت تثبه جذور الفطر عن قعورها ليست لغزاً ل الا حكاية إنه سقف غرفتي (32). فإذا كان الثعر انزياحاً في الخطاب، فإن الصورة الثعرية تؤثر في الانزياح الدلالي عبر جزئيات متعددة من أهمها الإيقاع

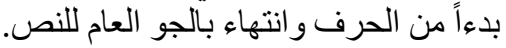

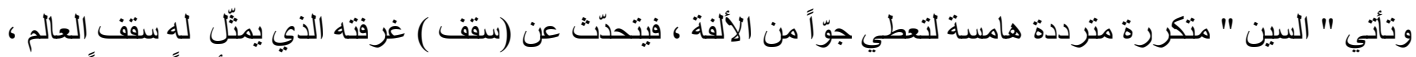

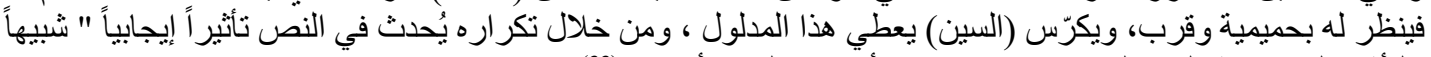
بالتأثير الذي يحدثه لحن الموسيقى، و وإن كان الأمر في الثعر أخفى "(33).

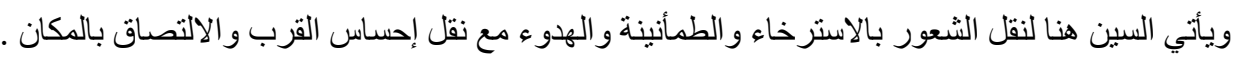
فعبر دو ال ( سماء ، سلة ، تسقط ، السماء ، ليست ، سقف ) يمكن الحديث عن (بساطة) يشير لها النص : ليست لغزاً ولا حكاية

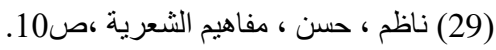

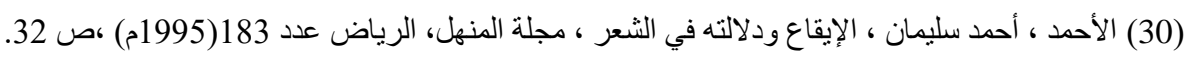

(31) عبيد ، محد صابر، القصيدة العربية بين البنية الدلالية والبنية الإيقاعية ، ص23.

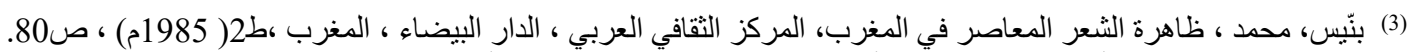

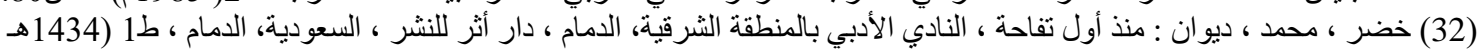

. (n) (

(33) عيّاد ، محمد شكري، موسيقى الثنعر العربي، دار المعرفة، القاهرة ، ط2 (1968م) ، ص 85. 


\section{شعرية الإيقاع الداخلي لقصيدة النثر السعودية}

إنه سقف غرفتي

حرف السين يقدّم إيقاعاً سهلاً بسيطاً في متناول الأذن لكون النص يسعى لايصال هذا المدلول السهل وغير المعقّد

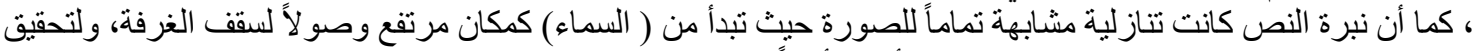

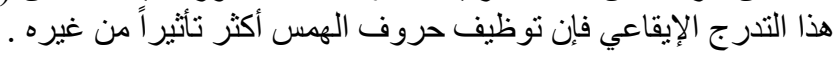

وتحت عنوان ( جذع مكسور ) يتردد حرف ( الحاء) عبر مجموعة من الدوال : جذع مكسور حين لا أجد أحداً على السري /أحمل نسل الرياح إلى منحدر في البعيد انتظر حتى يزهر النسيان على الأصسابع ووجهك يصبح بوصلة العالم حين لأجد أحداً. أصحبك على ضو ء القصيدة و أقف كجذع مكسور عند بابك(34)

يأتي الإيقاع هنا هادئاً ليعكس انفعالات الحزن و الحنين التي يحملها النص من خلال دو ال ( حين ، أحداً أحمل ،

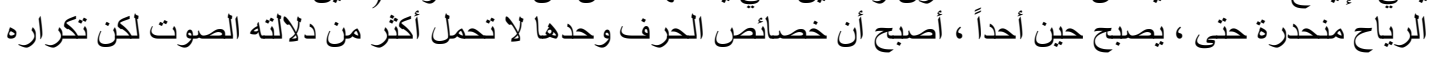

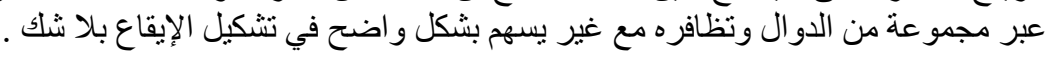

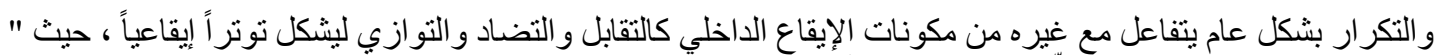

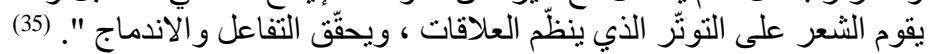

إن تكر ار ( الحاء) في النص السابق يكرس أجواء الحزن و الحنين والانكسار ، حيث يبدأ النص بها ، وينتهي إليها ، ( و أقف

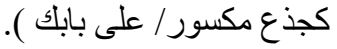
كما يثيع جوّاً من الإحساس بالغربة ( حين لأجد أحداً ) ، ويتردّد صوت الحاء مندمجاً مع صوت الريح و الوحشة : أحمل نسل الرياح إلى المنحدر البعيد.. وهو ما يشير إلى " أن التّكر ار الحديث ينزع إلى إبراز إيقاع در امي سيكولوجي "(36) ويتكرّر حرف ( التاء) منذ العنوان ( استدراج ) : تأتين مثل دخان يهوّم الر أس طيفك كان يحدّق بي وروائحه خطو اتي وكائنات نفضت دمي وتهدّمت

(34) زولي، إبر اهيم ، ديو ان : حرس شخصي للوحشة، المركز الثقافي العربي ، الدار البيضاء، بيروت ، ط (2015م) ، ص 11. (35) ناصف ، دصطفى ، مشكلة المعنى في النقد الحديث، مكتبة الثباب، القاهرة ، ط1( 1965م) ، ص 72. (36) عيد ، رجاء ، لغة الثعر( قراءة في الشعر العربي الحديث) ، دار المعارف الاسكندرية، ط1( 1998 م) ،ص 60. 


\section{شعرية الإيقاع الاخلي لقصيدة النثر السعودية}

تندلع الكائنات و لا أتعثّر

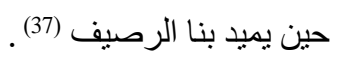

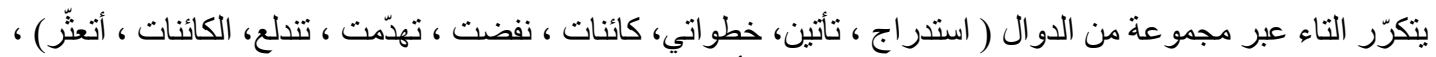

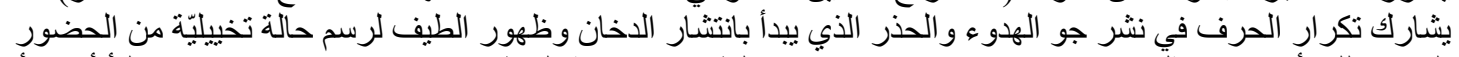

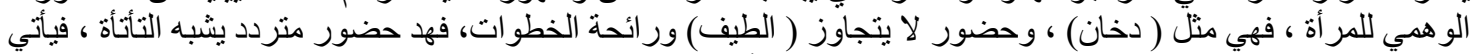

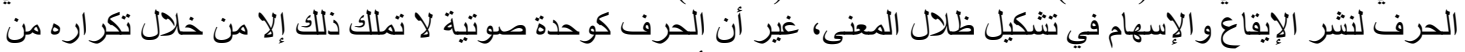

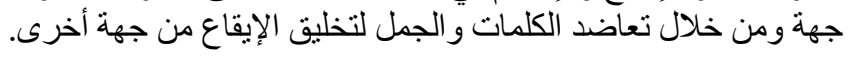

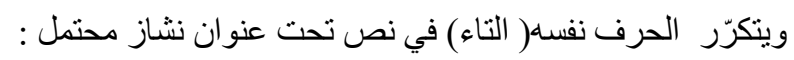
فكلما زرت بيت صديقي أحاول ألا تُسمع خطو اتي لا خوف معتادون هم على صمتي

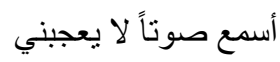
ظنون .. لا تمنعني طرق الباب. (38)

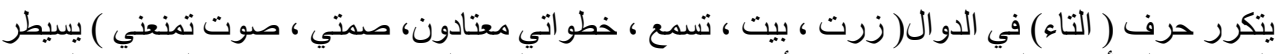

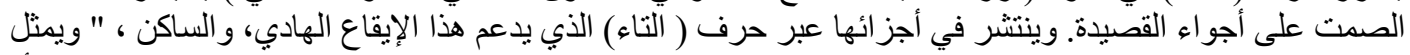

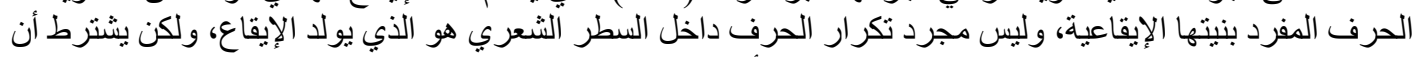

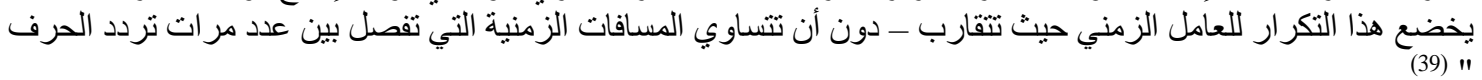

يلاحظ من خلال المقطع السابق هو ذلك التقارب في مواضع الحرف و الذي يعمل على نقل صوت الخطو ات الهادئة البعيدة عن الضجيج ، ومحاكاتها إيقاعيًاً.

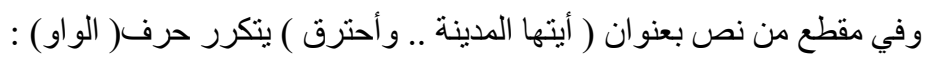
لا طرق على بابي /لا صوت للخطى و لا نسيم وحدي / والأنا و الكبرياء و عقلي

وإيماني الذي يمنعني (40) وعري

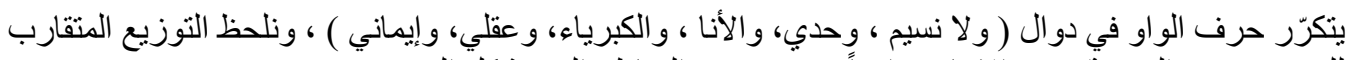
للحرف بهدف التسوية ومنح الإيقاع تو ازناً مع غيره من المقاطع التي تشكل القصيدة .

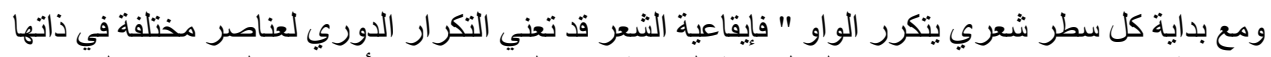

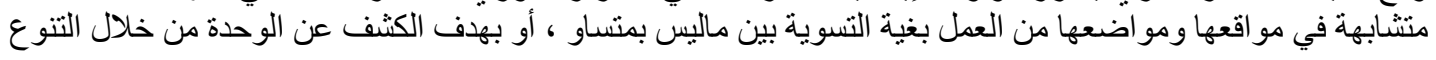

(38) ثابت ، عبد الله، ديوان الهتك ، إصدارات وزارة الثقافة صنعاء، اليمن ، ط1(2004م) ،ص 39. (39) مو افي ، عبد العزيز ، قصيدة النثر من التأسيس إلى المرجعية، المجلس الأعلى للثقافة، القاهرة ، ط1 (2004م) ،ص سل 301 ـ .

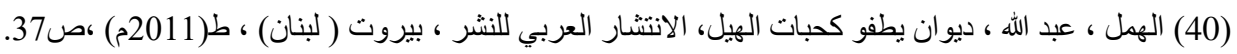




\section{شعرية الإيقاع الاخلي لقصيدة النثر السعودية}

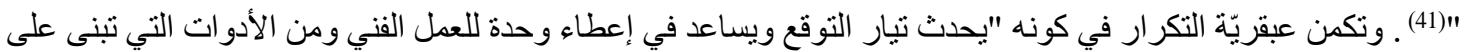

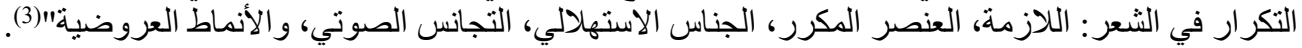

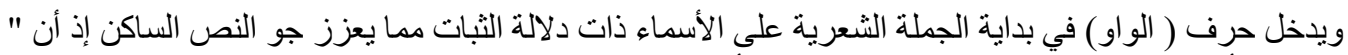
كل عمل أدبي فني - هو قبل كل شيء سلسلة من الأصوات يبحث عنها الأنها المعنى " (42).

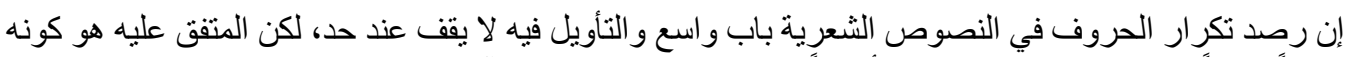

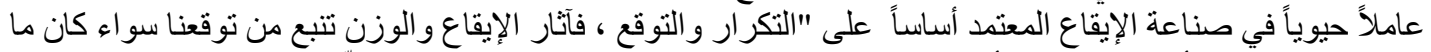

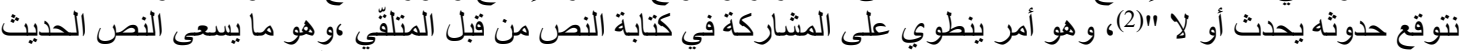

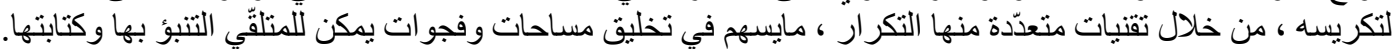

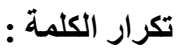

تكرار الوحدة المعجميّة أي تكرار الكلمة الواحدة في النص نفسه ، وهو ما " يظهر نصياً من خلال إعادة وحدة معجميّة وظفت سلفاً في سيّاق مشابه "(43). وسواء كانت الكلمة اسماً أفعلاً فإن لها أثراً في صناعة الإيقاع الداخلي ، مع اختلاف ذللك التأثير من صيغة لأخرى ومن نص لآخر . من أكثر النصوص توظيفاً للتكر ار نص تحت عنوان ( قابل للكسر ) : تحيّة للجر اح التي جفت من الحياد تحيّة لنشرة الأخبار التي لا تنتهي تحيّة للكناية في الأوجه الواضحة تحيّة للثطرنج و هو يغسلنا من الوثن

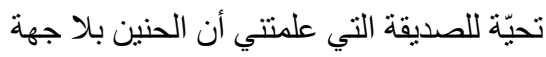

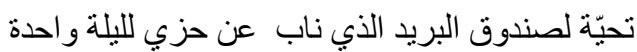

تحيّة للمذيعة التي تو عدتنا بالأحلام و المستقبل المضيء ثم لم نر ها مجدداً. (44) ).

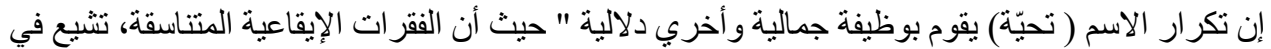
القصيدة لمسات عاطفية وجدانية يفر غها إيقاع المفردات المكررة بشكل تصحبه الدهثة ولئة المفاجأة ". (45).

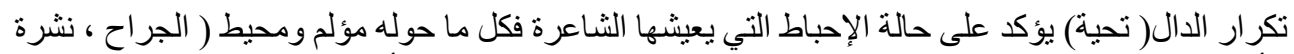

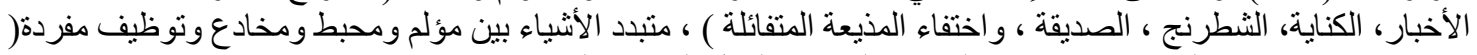
تحية) لإظهار سخرية الثاعر من مظاهر الزيف والخداء الخداع و الفنشل المحيط بالثاعر. كما تقوم المفردة بنشر إيقاعها السكوني لخدمة هدفها الجمالي و إيصاله للمتلقي .

(41) لوتمان ، يوري ، تحليل النص الثعري، ترجمة ، محمد أحمد فتوح، النادي الأدبي الثقافي بجدة ، ط1 (1999م) ، 16 . (3) عبد المطلب، محمد، بناء الأسلوب في شعر الحداثة ( التكوين البديعي) ، دار المعارف للطباعة والنشر ، القاهرة، طع(1995م) ،

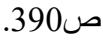
(42) ويليك ، رينيه ، و أوستن وارين ، نظرية الأدب، ترجمة : محي الدين صبحي، المؤسسة العربية للار اسات و النشر ، لبنان ( بيروت )

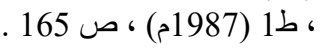

(2) أ..أ. رتثاردز ، مبادىء النقد الأدبي، ترجمة : مصطفى بدوي، مراجعة: لويس عوض،سهير القلماوي ، المركز القومي للترجمة -ـ

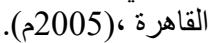

بوقرة ، نعمان ، مدخل إلى التحليل اللساني للخطاب الثنعري، عالم الكتب للنشر ، عمان ، ط1(2009م) ، ص 38.

خضر، محمد ، ديو ان منذ أول تفاحة ، صلى 72.

(45) إسماعيل، عز الدين، الثعر العربي المعاصر(قضاياه وظو اهره الفنية والمعنويّة) ، دار العودة، ط 3(1994م ) ، ص 166. 


\section{شعرية الإيقاع الاخلي لقصيدة النثر السعودية}

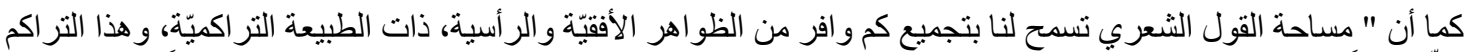
يولّّ نو عاً من الإيقاع الداخلي والخارجي، على صعيد واحد لا يقل عن الإيقاع العروضي، إن لم يتجاوزه أحياناً كثيرة "(46).

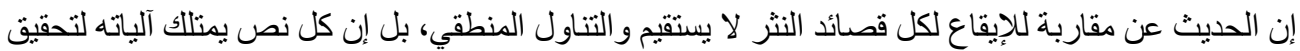
إيقاعاته و أهدافه الإبداعيّة و الجماليّة . تتكرّر في نص ( عادة مدرسية ) كلمة رائحة : كانت أصابعهم الأفَّاقة تعرف ر ائحة غير مناسبة رائحة تفيض منهم

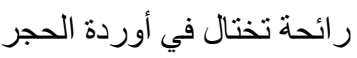
رائحة تقف بكبرياء حتى إنشعار آخر

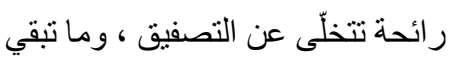

من فوضى البرد(47)

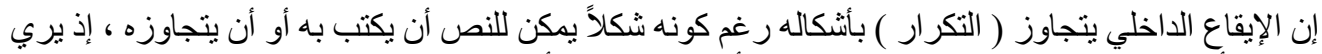

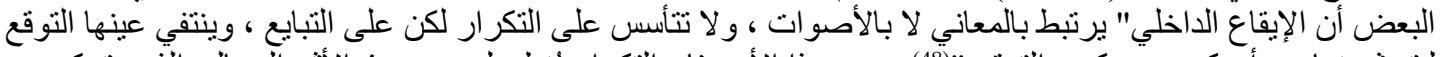

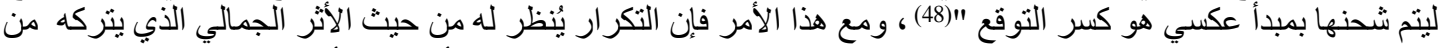

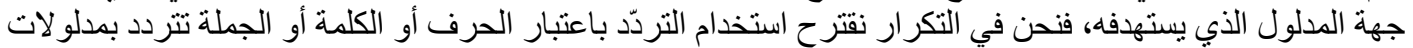
مختلفة تتجاوز مجرد التكرار.

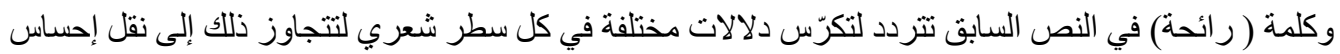

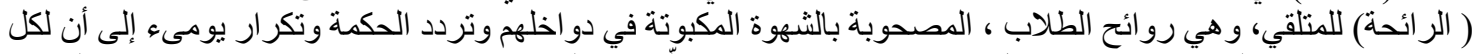

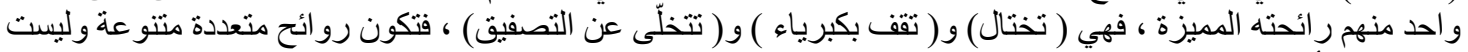

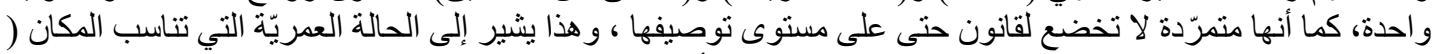

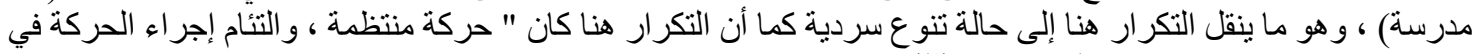

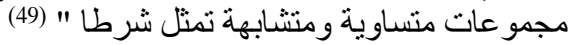

و التتكرر كلمة ( أناثشيد) في نص ( كحقائب السفر) : في تباطؤ ، تجرحه الذكريات المكفهرة، لم أرهو وهو يحرض

الأناشيد المتروكة، الأنانثيد التي تنبض في حصي الكلام ..

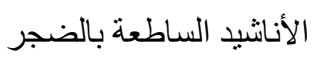

الأناشيد التي ترفع قبضنتها و لا تبالي

الأناثيد الخارجة بمفردها

مخفورة بالجوار ح و اللعنات (50).

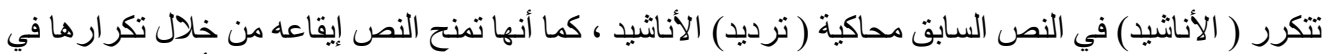

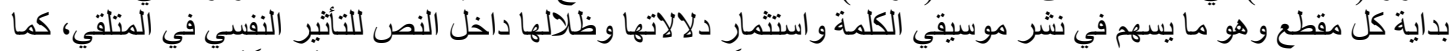

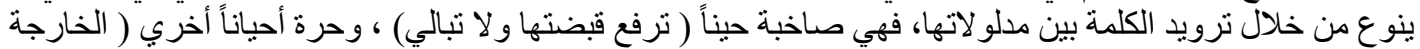
بمفردها)، و هي مشرقة ( ساطعة رغم الثجر و الهز ائم ) .

(46) عبد المطلب ، محمد، النص المشكل ، سلسلة كتابات نقدية، هيئة قصور الثقافة، (1995م) ،ص 217.

(47) زولي ، إبر اهيم، ديو ان حرس شخصي للوحشة، ص 21 ، 22 .

(48) مو افي ، عبد العزيز ، قصيدة النثر من التأسيس إلى المرجعية، ص 296.

(49) عياد، شكري ، موسيقي الثعر ، دار المعرفة ، ط2 ( 1978م) ، ص 57 .

(50) زولي ، إبر اهيم ، ديوان حرس شخصي للوحشة ، ص 83. 


\section{شعرية الإيقاع الداخلي لقصيدة النثر السعودية}

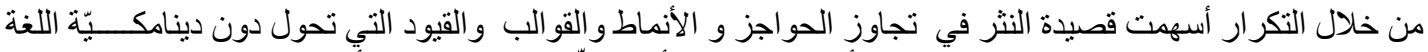

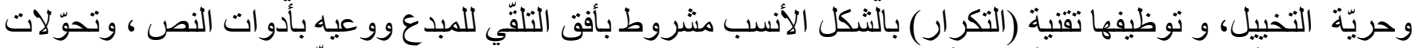

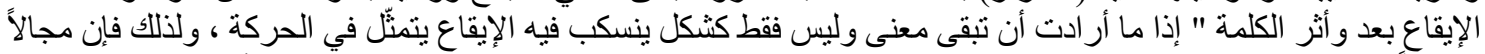

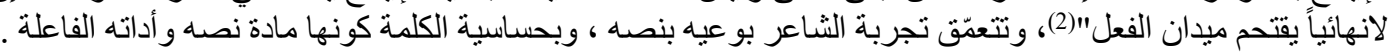

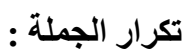

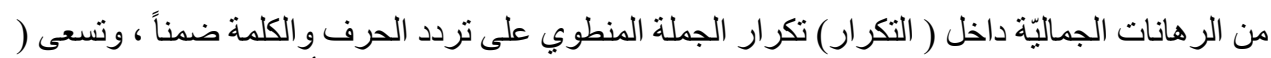

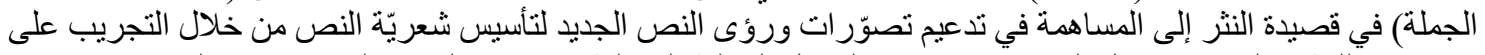

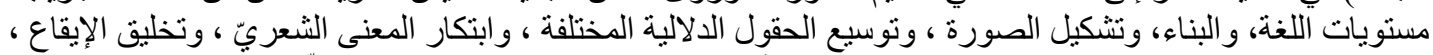

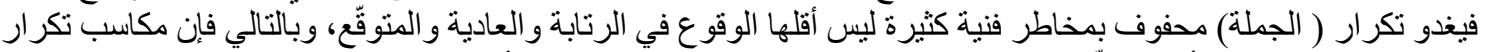

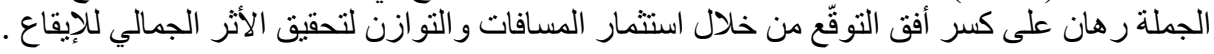

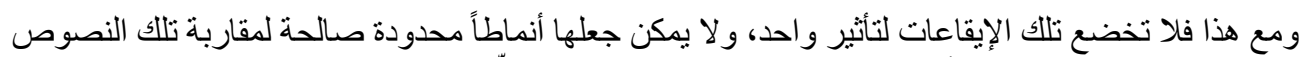

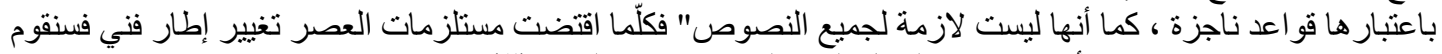

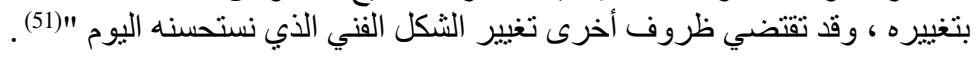

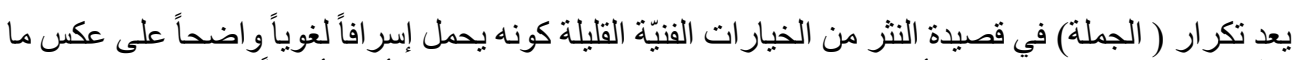

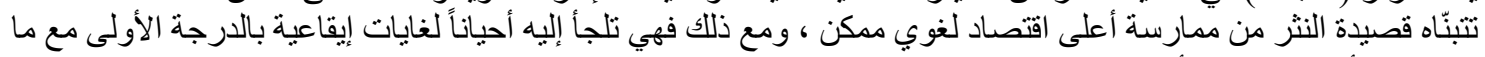

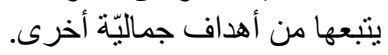

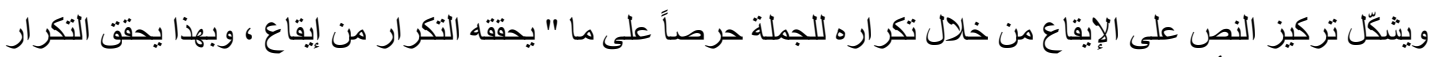

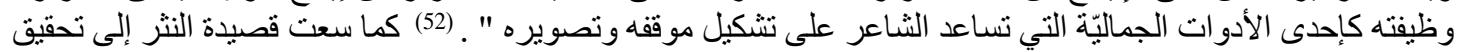

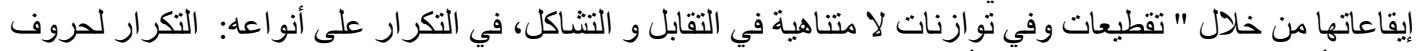

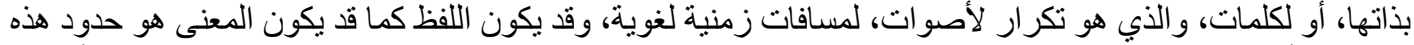

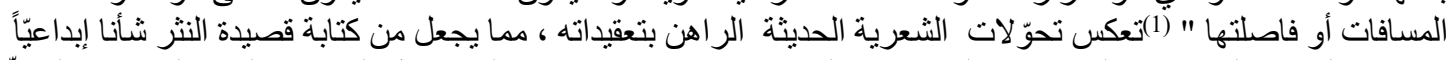

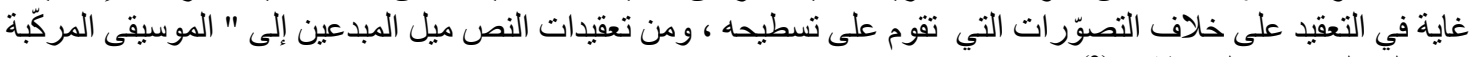
منهم إلى الموسيقى البسيطة" "(2). في نص ( الولد) تتكرر جملة ( الولد الذي خرج ) لمرتين " الولد الذي خرج ذاهلاً : دون أن يعلم أبو اه عنه شيئًاً

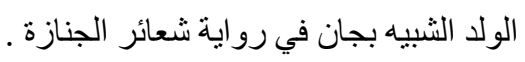
الولد الذي استوى شجراً في حقول التوجّس

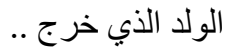
كان محتشداً بآثامه ولم يعد يعرف طريقاً إلى أهله (3)

(2) غيور غي ، غاتثف، الوعي والفن (دراسات في تاريخ الصورة الفنية) ترجمة: نوفل نيوف ، سلسلة عالم المعرفة ، العدد:146،

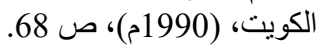

(51) ينحدَث عبد القادر القط عن قصيدة التفعيلة لكنه حديث يمكن أن يجري على الفنون التي من طبيعها التطور الدائم ، انظر : القط ،

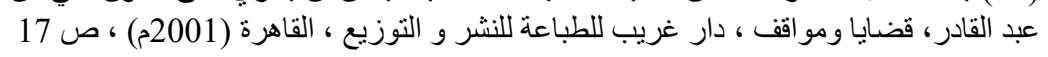

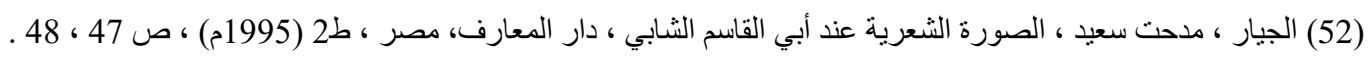

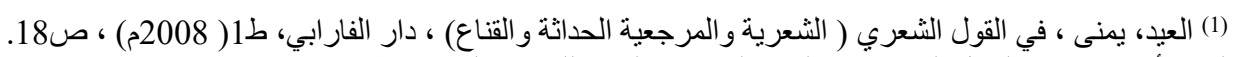

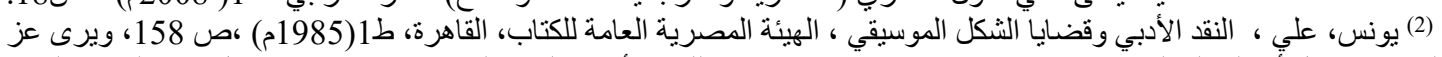

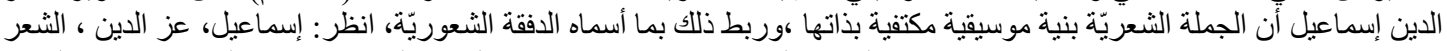

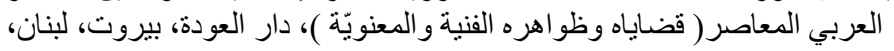

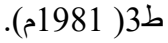

(3) زولي ، إبر اهيم ، ديو ان حرس شخصي للوحشة، ص 13 ، 14 . 


\section{شعرية الإيقاع الاخلي لقصيدة النثر السعودية}

يمثل النص هنا تمثيلاً" ا للدفقة الشعورية الواحدة، فتكون القصيدة النثرية مجموعة دفقات شعوريّة يسكبها الخيال الفني"(4).

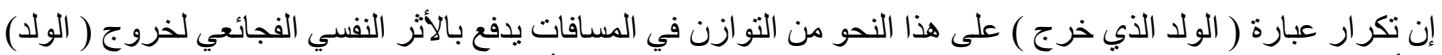

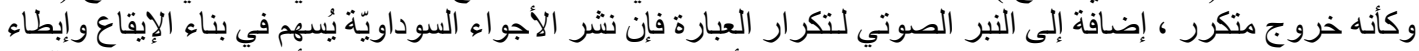

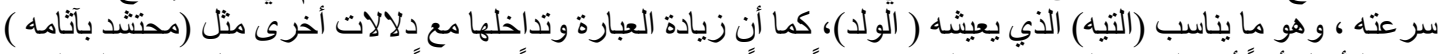

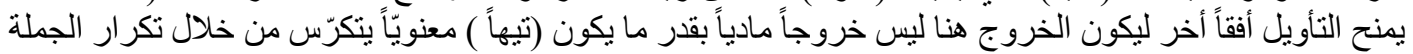
و إيقاعها الرنيب . التربل

$$
\begin{aligned}
& \text { وتتكرّر جملة ( كان صادقاً) في نص تحت عنوان ( كأننا لم نكبر يوماً) : } \\
& \text { كان صـادقاً وهو يخبرنا }
\end{aligned}
$$

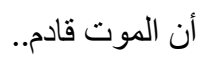

$$
\begin{aligned}
& \text { بأية طريقة } \\
& \text { كلما توسلنا إليه.. } \\
& \text { أن يخفف من حاسة الكو ابح. } \\
& \text { كان صادقاً أيضاً في رحيله (53). }
\end{aligned}
$$

لتشكيل الإيقاع يصبح " انتخاب شطر شعري وجملة شعرية تشكّل بمستو ييها الإيقاعي و الدلالي محور اً من محاور

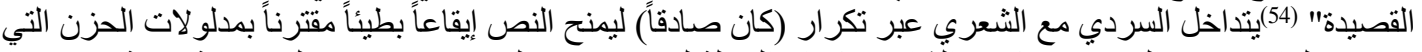

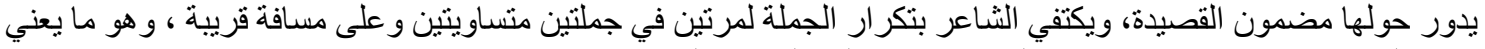
وعي الثاعر بضبط الإيقاع ونوظيفه لخدمة الإيقاع العام لمقاطع النصاع. لخدئ

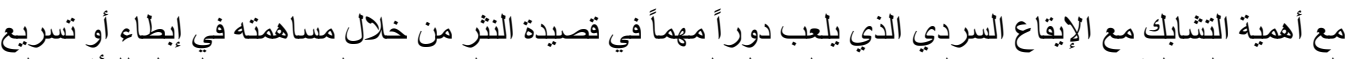

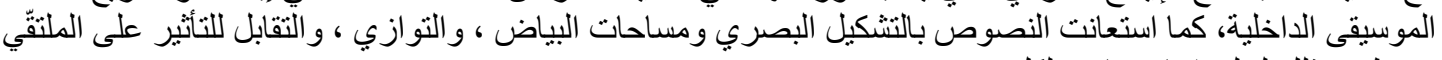
وتوظيف ذلك لخلق إيقاع خاص لكل نصائ.

إيقاع التقابل / التضاد :

سعى بعض شعر اء قصيدة النثر إلى استثمار بعض القضايا الأسلوبية لتخليق الإيقاع ليس لتعويض الأوزان

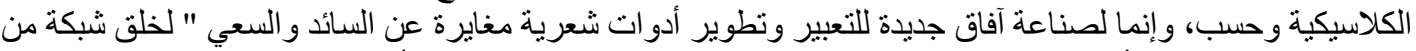

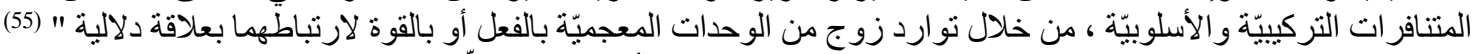

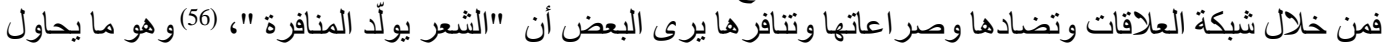

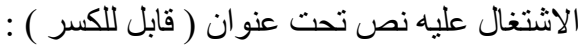

$$
\begin{aligned}
& \text { للجغر افيا صورة الأبيض و الأسود. } \\
& \text { للساحات ذاكرتها المؤودة . } \\
& \text { للموتى أن يمسو ا جنباً إلى جنب كل صباح } \\
& \text { من صرخة الولادة }
\end{aligned}
$$

\footnotetext{
(4) المناصرة ، عزّ الدين ، إثكاليات قصيدة النثر ( نصّ مفتوح عابر للأنواع ) ، المؤسسة العربيّة للار اسات و النشر، بيروت، لبنان، ط ،

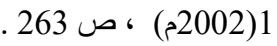

$$
\text { . } 48 \text { (53) خضر ، محمد ، منذ أول تفاحة ،ص } 48
$$$$
\text { (54) عبيد ، محمد صابر، القصيدة العربية بين البنية الدلالية والبنية الإيقاعية، اتحاد الكتاب العرب ، دمشق ،ط1( 2001م)، ص } 206 .
$$$$
\text { (55) بوقرة ، نعمان ، مدخل إلى التحليل اللساني للخطاب الشعري ، ص } 38 \text { ـ }
$$$$
\text { (56) كو هن ، جون ، بنية اللغة الشعرية ، ترجمة : محمد الولي ، دار توبقال للنشر ، الدار البيضاء ، ط1 ( 1986م ) ، ص } 207 .
$$ 


\section{شعرية الإيقاع الاخلي لقصيدة النثر السعودية}

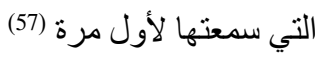

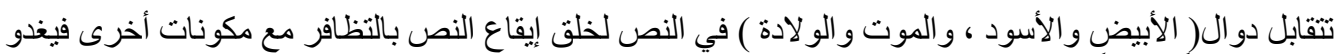

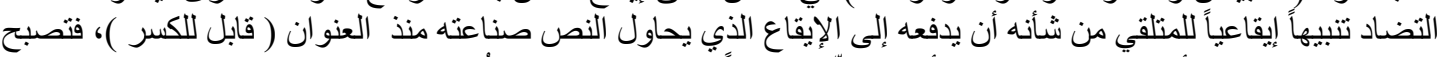

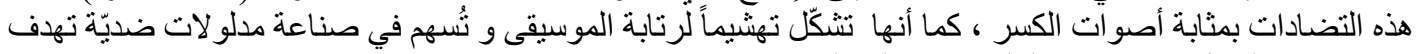

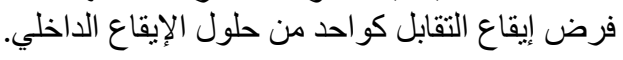

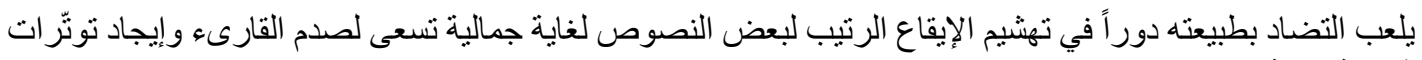
شعرية مهمة.

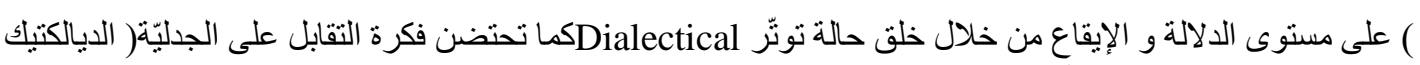

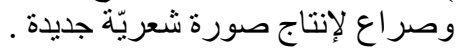

$$
\begin{aligned}
& \text { وفي هذا السياق يسعى الثناعر لغاياته الجماليّة في نص تحت عنوان ( عرض الثنتاء ) . } \\
& \text { و وأنت تطلّ على حنينك البعيد } \\
& \text { صاعداً على حافة الثهو ات لثن } \\
& \text { تسقط من علوّ شاهثق } \\
& \text { وتكون عرضة للنشتاء ... }
\end{aligned}
$$

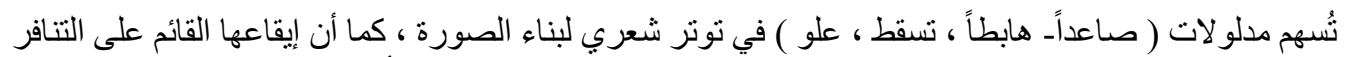

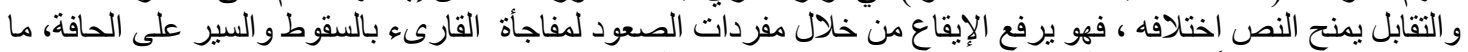

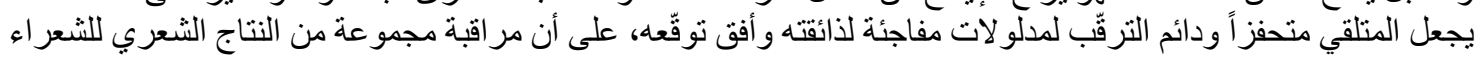

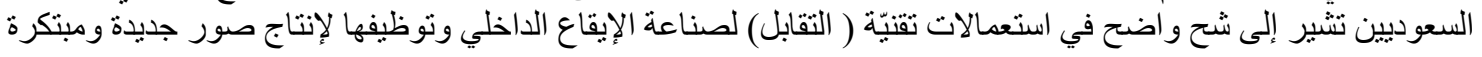

$$
\begin{aligned}
& \text { ومن أمثلة التضاد ، ما نجده تحت عنوان ( طين الرأس السنة ) : } \\
& \text { مكالمة كر أس السنة }
\end{aligned}
$$

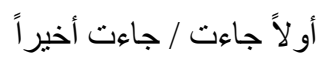

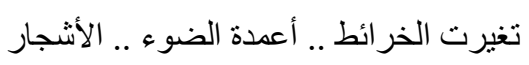

$$
\begin{aligned}
& \text { أنواع السيار ات.. الليل } \\
& \text { رقص يوستع ضيق العالم(59) }
\end{aligned}
$$

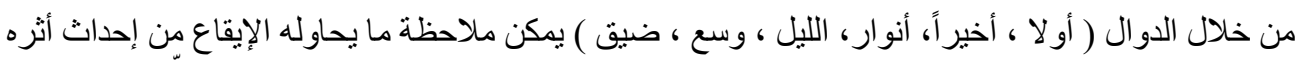

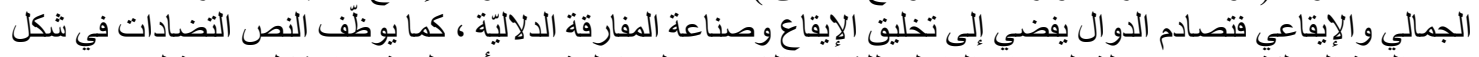

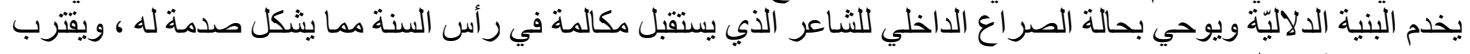

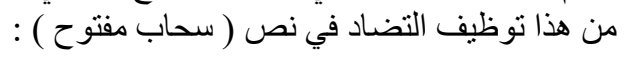

الضوء يمزق الظلام

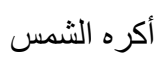

أكره النوم

أكره نفسي

$$
\begin{aligned}
& \text { خضر ، محمد ، ديو ان منذ أول تفاحة ، ص } 70 \text {. } \\
& \text { زولي ، إبر اهيم ، ديو ان حرس شخصي للوحشة ،ص } 57 \text { ـ . }
\end{aligned}
$$

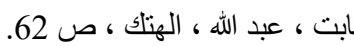




\section{شعرية الإيقاع الاخلي لقصيدة النثر السعودية}

أكر هكم

حاول إقفال النافذة

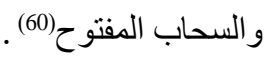

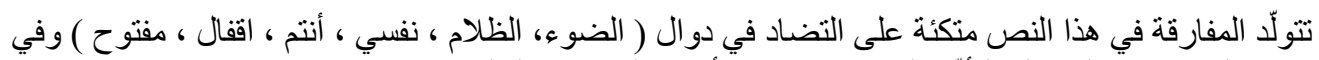
رغبة الثاعر في فلك حالة التأزّم التي يعيشها حتى أصبح له مو لفه السلبي من نفسه ومن محيطه .

إن صناعة الإيقاع لا تقوم عبر مكوّن واحد في الخطاب الثعري ، و إنما تتظافر عبر مجموعة الآليات لتخليق الموسيقي

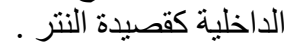

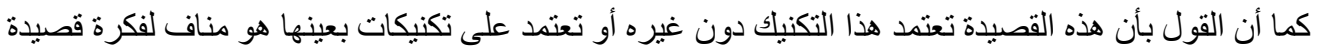

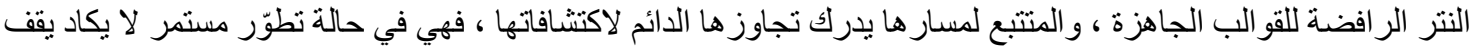
عن حد ، كما أن ما توظفه القصيدة من آليات وأساليب يختلف من نص إلى أخر الته ومن شاعر لآخر.

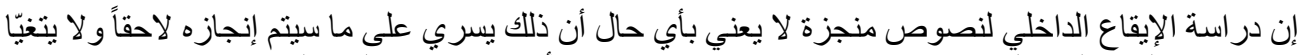

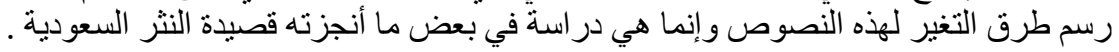

الخاتمة

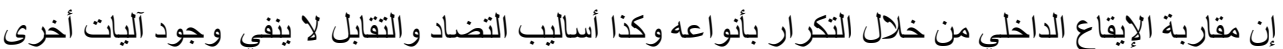

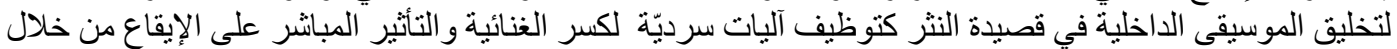

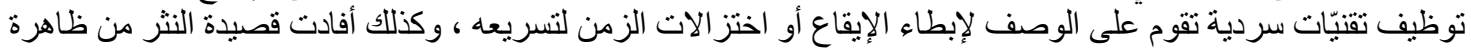

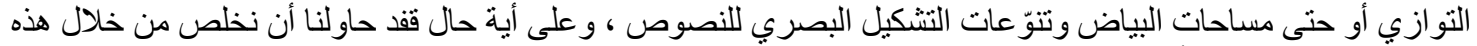

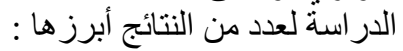

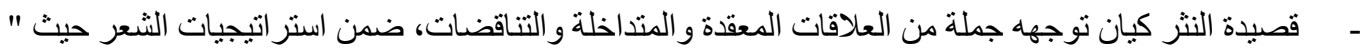

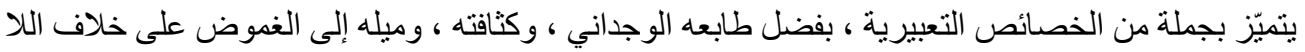

شعري (61)

- متمارس قصيدة النثر السعودية حضور ها عبر عدد من البنى العميقة أبرز ها بنية التفاعل مع المنجز الثعري في

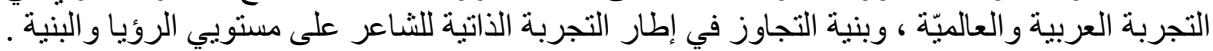

- اءت قصيدة النثر السعودية محملة بأسئلة الإبداع و القلق الثعري والجمالي.

- وظفت قصيدة النثر السعودية آليات تخليق الإيقاع الداخلي حينت وتجاوزته حيناً آخر.

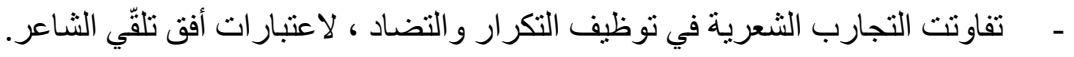

- اختلف الثعر اء في توظيف الإيقاع الداخلي لخدمة الدلالة وتحقيق الرؤى المختلفة.

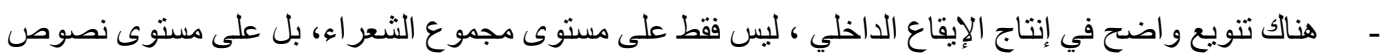

الثشاعر نفسه.

- تسعى قصيدة النثر السعودية إلى تشكيل رؤاها الخاصة وسط راهن ثقافي يغلب عليه الرفض.

- ل التز ال قصيدة النثر السعودية بحاجة إلى الدراسة النقدية الجادة لترشيد التجربة ومنحها أفقاً جديداً.

(60) الهمل ، عبد الله ، ديوان يطفو كبات الهيل ،ص 75.

(61) حميد، رضا ، الخطاب الثعري الحديث من اللغوي إلى التثكيل البصري، مجلة فصول ، م ه عدد 2 ، ج1 ( 1996م) ،ص 65 ، 


\section{شعرية الإيقاع الاخلي لقصيدة النثر السعودية}

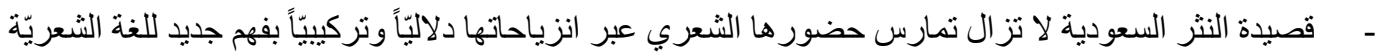

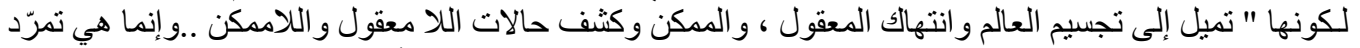
في المقام الأول على موضول علة شعريّة ". (62)

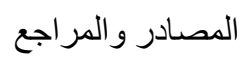

ـ أحمد ، محمد فنوح ، الحداثة الثعرية (الأصول و التجليات ) ، دار غريب للنشر ، القاهرة ، ط1(2007م). ـ ـ الغزّي، محمد ، وجوه النرجس ... مر ايا الماء ( دراسة في الخطاب الواصف في الثنعر العربيّ الحديث) ،دار

مسكيلياني للتوزيع و النشر، تونس، طالنس ( 2000م).

ـ ـ أدونيس ، زمن الثعر ، دار العودة ، بيروت ( لبنان ) ، ط3( 1982م).

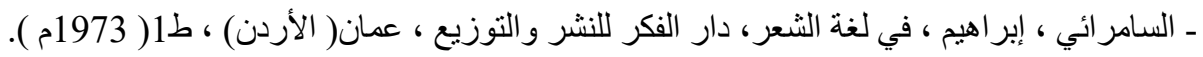

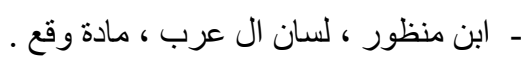

ـ ـ الصباغ ، رمضان ، في نقد الثعر العربي المعاصر( دراسة جمالية) ، دار الوفاء للنشر ،الأسكندريّة ،

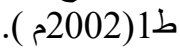

ـ ـ أدونيس، في قصيدة النثرِ ، مجلَّة شعر، العدد( 14) ، سنة (1960م).

ـ - الضبع ، محمد ، قصيدة النثر وتحو لات الشعرية الغربية ، الثركة الدولية ، للطباعة ، ط1(2003م) .

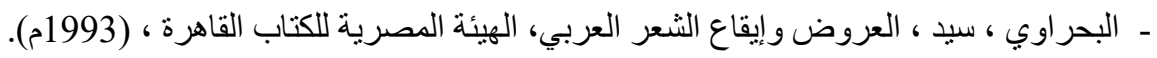

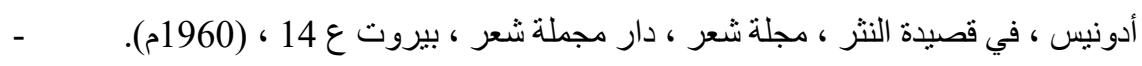

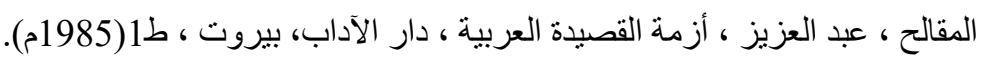

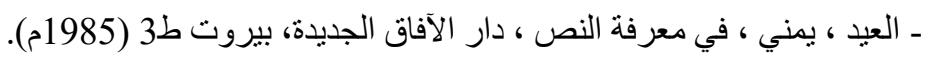

ـ ـ المناصرة ، عز الدين ، علم الشعريات ( قراءة مونتاجية في أدبية الأدب ) ، دار مجدلاوي ، عمان ، (2007م).

ـ - أبو ديب ، كمال ، في الثعرية ، مؤسسة الأبحاث العربية، بيروت لبنان ، ط1(1997م.

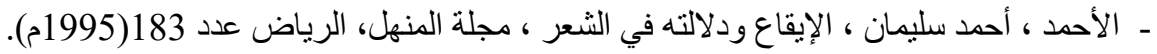

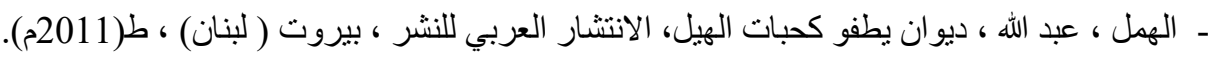

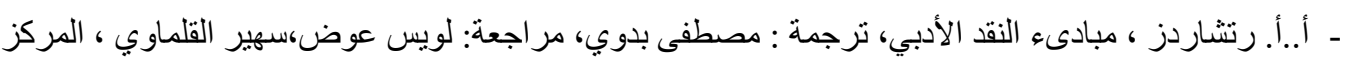

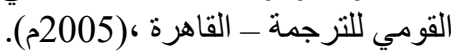

- إسماعيل، عز الدين، الثعر العربي المعاصر (قضاياه وظو اهره الفنبة والمعنويّة) ، دار العودة، ط 3(1994م ) ).

ـ القط ، عبد القادر، قضايا ومو اقف ، دار غريب للطباعة للنشر و التوزيع ، القاهرة (2001م) .

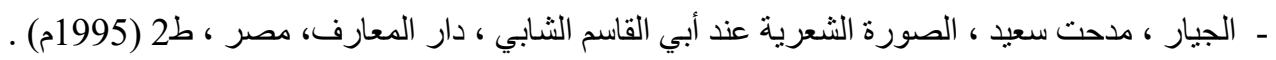

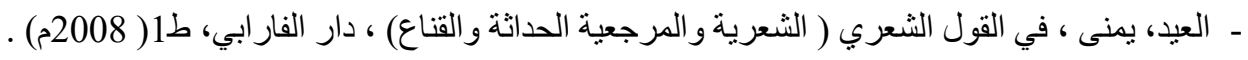

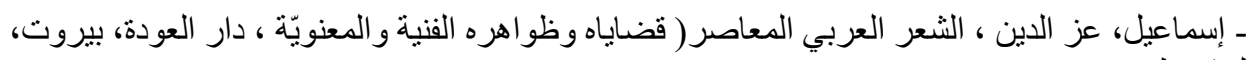

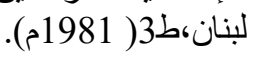

ـ ـ المناصرة ، عزّ الدين ، إثكاليات قصيدة النثر ( نصّّ مفتوح عابر للأنواع ) ، المؤسسة العربيّة للار اسات و النشر ، بيروت، لبنان، ط الن ، (2002م) .

ـ الضبع ، محمود إبر اهيم ، قصيدة النثر وتحو لات الثعرية العربية ، الهيئة العامة لقصور الثقافة، القاهرة ،

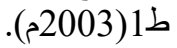

(62) الضبع ، محمود إبر اهيم ، قصيدة النثر وتحو لات الثعرية العربية ، ص 308. 


\section{شعرية الإيقاع الاخلي لقصيدة النثر السعودية}

- بو منجل ، عبد الملك ، جدل الثابت والمتغير في النقا العربي الحديث ، عالم الكتب، ج2، ط1(2010م ) .

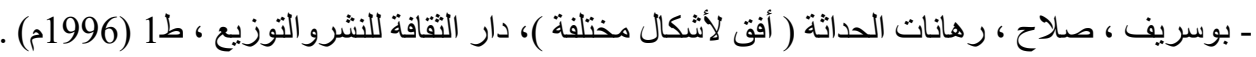

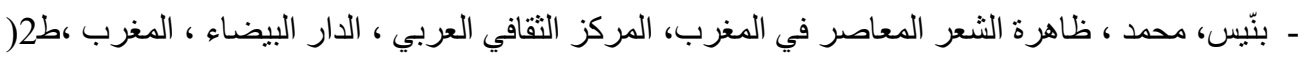
.) (1985

- بوقرة ، نعمان ، مدخل إلى التحليل اللساني للخطاب الثعري، عالم الكتب للنشر ، عمان ، ط1(2009م) .

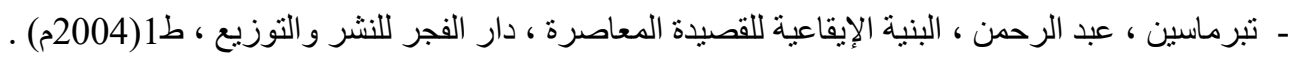

- تبرماسين ، عبد الرحمن ، العروض و إيقاع الثعر العربي ، دار الفجر للنشر ، القاهرة ط1(2003م).

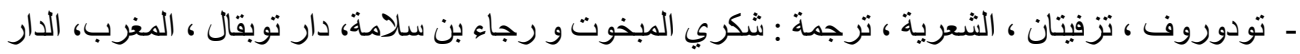

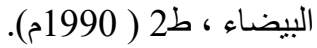

ـ ثابت ، عبد الله، ديو ان الهتاك ، إصدار ات وزارة الثقافة صنعاء، اليمن ، ط1(2004م) .

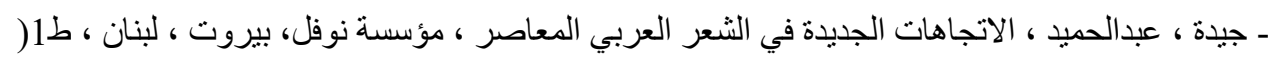
1980م) (1950)

- حميد، رضا ، الخطاب الثعري الحديث من اللغوي إلى التثكيل البصري، مجلة فصول ، م ه عدد 2 ، ج1 (1980)

- حسين ، عبدالكريم ، عمود الثعر (مو اقعه ووظائفه وأبو ابه ) ، دار النمير للطباعة ، دمشق ،ط1(2003م).

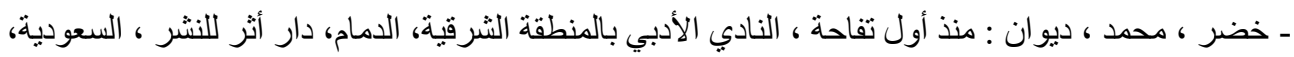

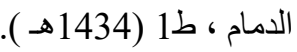

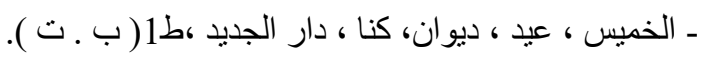

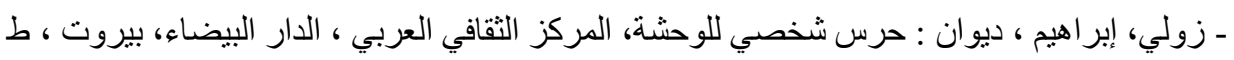
(2015)

ـ سوريو ، اتيين، الزمان في الفنون التثكيلية ، ترجمة : سعد عبدالمحسن ، مجلة آفاق عربيّة ، عدد 3، السنة الثالثة

ـ سعيد ، خالدة ، حركية الإبداع ( در اسات في الأدب العربي الحديث)، دار الفكر ، بيروت (لبنان)، ط3 .)(1986)

ـ سليمان ، خالد ، الجذور و الأنساغ ( در اسة نقدية في جديد القصيدة العربية المعاصرة ) ، ط 1986(2009م) .

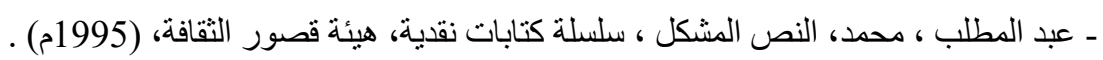

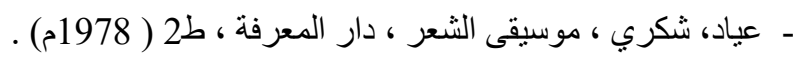
ـ عبيد، محمد صابر، القصيدة العربية الحديثة بين البنية الدلالية والبنية الإيقاعية، منشورات اتحاد الكتاب العرب،

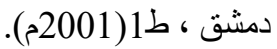

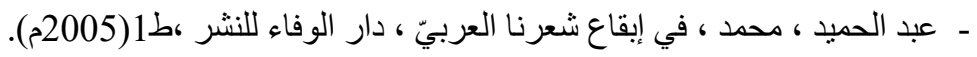
- عيسي ، فوزي ، النص الثعري و آليات القراءة، المعارف ( مصر ( د. ط ) ، (1997م).

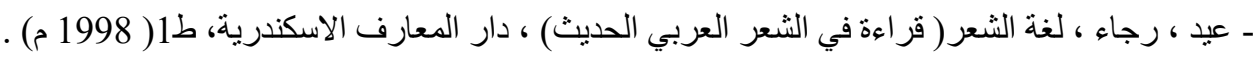

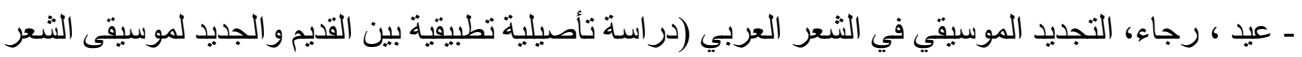
العربي) ، دار الفكر ، بيروت طاهئ (1998م).

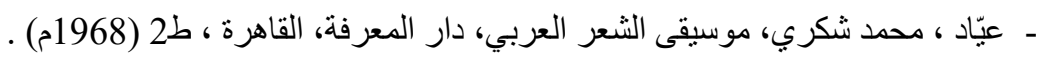
ـ عبد المطلب، محمد، بناء الأسلوب في شعر الحداثة ( التكوين البديعي) ، دار المعارف للطباعة والنشر ، القاهرة،

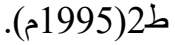




\section{شعرية الإيقاع الداخلي لقصيدة النثر السعودية}

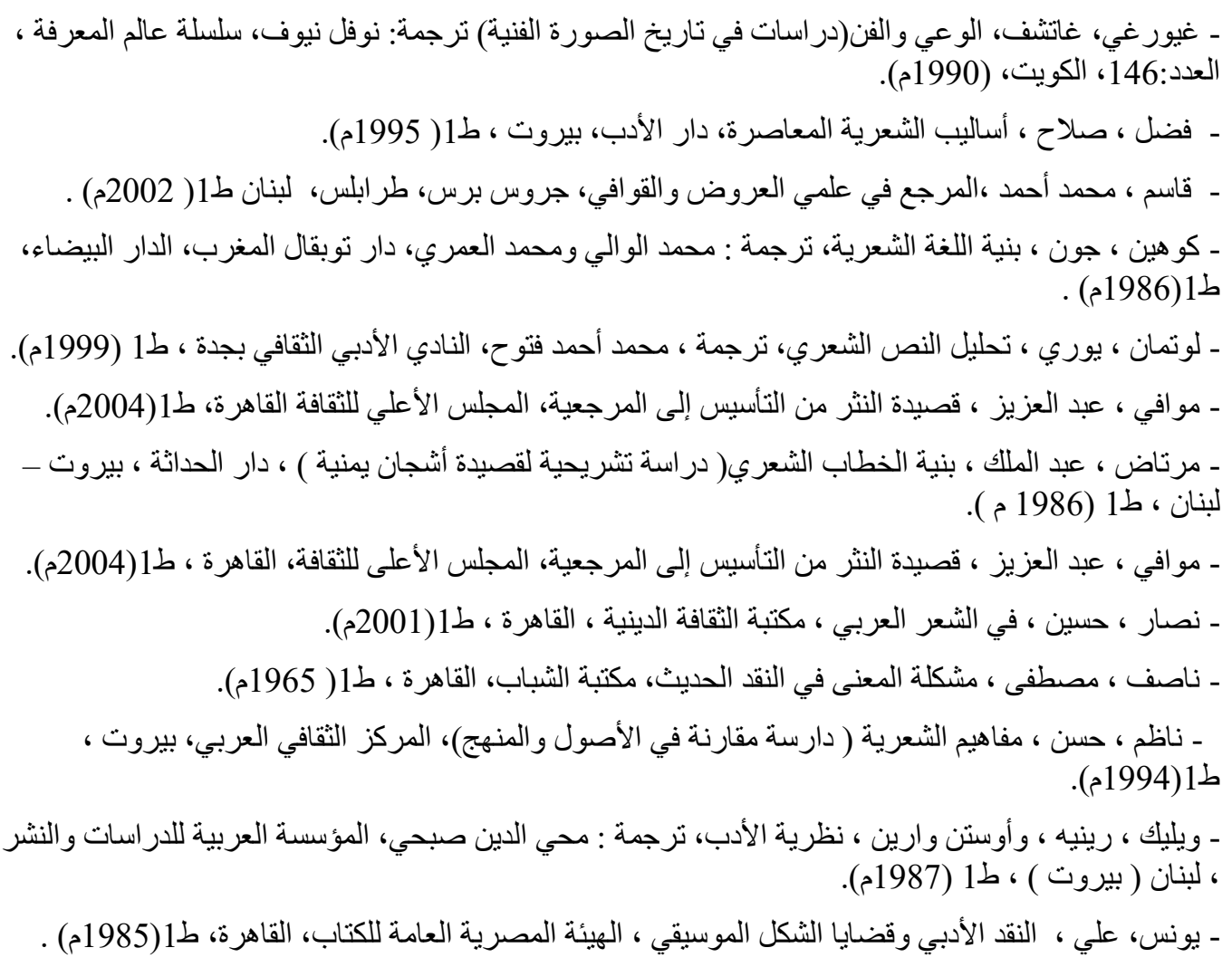

